\title{
Auxotrophy to Xeno-DNA: an exploration of combinatorial mechanisms for a high- fidelity biosafety system for synthetic biology applications
}

Christopher M. Whitford ${ }^{1}$ DD, Saskia Dymek ${ }^{1}$ Denise Kerkhoff ${ }^{1}$, Camilla März ${ }^{1}$, Olga Schmidt ${ }^{1}$, Maximilian Edich', Julian Droste ${ }^{1,2}$, Boas Pucker $^{1,2,3}$ (D), Christian Rückert ${ }^{1,2}$ (D) and Jörn Kalinowski ${ }^{1,2^{*}}$

\begin{abstract}
Background: Biosafety is a key aspect in the international Genetically Engineered Machine (iGEM) competition, which offers student teams an amazing opportunity to pursue their own research projects in the field of Synthetic Biology. iGEM projects often involve the creation of genetically engineered bacterial strains. To minimize the risks associated with bacterial release, a variety of biosafety systems were constructed, either to prevent survival of bacteria outside the lab or to hinder horizontal or vertical gene transfer.

Main body: Physical containment methods such as bioreactors or microencapsulation are considered the first safety level. Additionally, various systems involving auxotrophies for both natural and synthetic compounds have been utilized by iGEM teams in recent years. Combinatorial systems comprising multiple auxotrophies have been shown to reduced escape frequencies below the detection limit. Furthermore, a number of natural toxin-antitoxin systems can be deployed to kill cells under certain conditions. Additionally, parts of naturally occurring toxinantitoxin systems can be used for the construction of 'kill switches' controlled by synthetic regulatory modules, allowing control of cell survival. Kill switches prevent cell survival but do not completely degrade nucleic acids. To avoid horizontal gene transfer, multiple mechanisms to cleave nucleic acids can be employed, resulting in 'selfdestruction' of cells. Changes in light or temperature conditions are powerful regulators of gene expression and could serve as triggers for kill switches or self-destruction systems. Xenobiology-based containment uses applications of Xeno-DNA, recoded codons and non-canonical amino acids to nullify the genetic information of constructed cells for wild type organisms. A 'minimal genome' approach brings the opportunity to reduce the genome of a cell to only genes necessary for survival under lab conditions. Such cells are unlikely to survive in the natural environment and are thus considered safe hosts. If suitable for the desired application, a shift to cell-free systems based on Xeno-DNA may represent the ultimate biosafety system.
\end{abstract}

Conclusion: Here we describe different containment approaches in synthetic biology, ranging from auxotrophies to minimal genomes, which can be combined to significantly improve reliability. Since the iGEM competition greatly increases the number of people involved in synthetic biology, we will focus especially on biosafety systems developed and applied in the context of the iGEM competition.

Keywords: Kill switch, iGEM, Semantic containment, Physical containment, Auxotrophy, Escherichia coli, BioBrick, Genetic engineering

\footnotetext{
* Correspondence: joern@cebitec.uni-bielefeld.de;

joern.kalinowski@cebitec.uni-bielefeld.de

${ }^{1}$ Center for Biotechnology, Bielefeld University, 33615 Bielefeld, Germany

${ }^{2}$ Faculty of Biology, Bielefeld University, Bielefeld, Germany

Full list of author information is available at the end of the article
}

(c) The Author(s). 2018 Open Access This article is distributed under the terms of the Creative Commons Attribution 4.0 International License (http://creativecommons.org/licenses/by/4.0/), which permits unrestricted use, distribution, and

reproduction in any medium, provided you give appropriate credit to the original author(s) and the source, provide a link to the Creative Commons license, and indicate if changes were made. The Creative Commons Public Domain Dedication waiver (http://creativecommons.org/publicdomain/zero/1.0/) applies to the data made available in this article, unless otherwise stated. 


\section{Background}

Safety approaches in synthetic biology are frequently distinguished into mechanisms of biosecurity or biosafety. However, many methods can only be distinguished at a theoretical level into biosafety or biosecurity [1]. Here, we focus on biosafety, defined as the combination of all preventive measures against accidental infection with, or release of, genetically engineered organisms into the environment [2]. Nevertheless, some of the presented mechanisms can also contribute to biosecurity, defined as the protection of biological systems against an intended misuse [3].

Recombinant DNA technology has been applied since 1973 to modify the genetic information of cells for scientific as well as for economic purposes [4]. However, this technology poses risks if applied carelessly [5] or with deleterious intent [6-8]. This risk has long been recognized, and multiple safety regulations have been proposed to prevent harm to humans, animals, and the environment $[9,10]$.

As Escherichia coli became a model organism in molecular biology and biotechnology, the development of safety strains was of high interest [11]. For example, $E$. coli K12 MG1655 [12, 13] and E. coli B derivatives like REL606 and BL21 (DE3) are safety strains [14] commonly used for molecular cloning and heterologous gene expression [15-19]. Due to several mutations, these strains are no longer able to compete with wild type strains within the human gut $[5,20]$. More sophisticated strains have been developed, including dedicated biosafety approaches like the relA deletion in combination with a conditional phoA expression [21, 22], as described in the next chapter. The combination of different precautions may have successfully prevented any accidents involving genetically modified organisms (GMOs) during the last four decades [2, 23-25]. Today, the handling of GMOs is strictly controlled for multiple reasons, including ecological and health considerations [2, 26, 27], but also the protection of intellectual property [28].

However, the demand for novel biosafety systems is still high, due to the spread of genetic engineering capabilities which in turn is facilitated by the growing number of people involved in the field of synthetic biology. Students participating in the iGEM [29] competition have contributed significantly to the synthetic biology toolbox [30-43]. The increased availability of genome sequences $[12,44]$ as well as an ever-increasing number of sequenced bacterial genomes could enhance the discovery and implementation of innovative safety systems. We will describe general biosafety mechanisms along with advanced systems developed within this competition. It is our intention to provide an overview of the applied concepts as well as the completely implemented and characterized systems. Since the deletion of an essential gene is probably the most basic mechanism, we will start with the description of auxotrophies. Released cells with failing auxotrophy systems could be stopped by the activation of kill switches. Activation of such mechanism should kill the cell, but the nucleic acids are still present, requiring a self-destruction of the genetic information to prevent horizontal gene transfer (HGT). Given that all known life on earth is based on the same biochemistry, cells are composed of common materials like proteins, sugars, lipids, and nucleic acids. Although the sequence of nucleotides and amino acids varies within higher layer molecules, the basal molecules are shared across all species. A common genetic code allows the exchange of genetic information between different species through HGT. In general, HGT might not be beneficial for a specific species [45] but is assumed to maintain an overall unity of life by preventing changes in the genetic code [46]. Therefore, central signal and metabolic pathways are shared between distantly related species, while additional pathways are specific to certain taxonomic groups. Interesting in terms of biosafety are rare cases, where replicating systems escaped this system and modified their genetic code [47-49]. Modifications to this universal genetic code pose a powerful biosafety mechanism [50]. Therefore, xenobiology-based containment is another way to prevent the successful transfer of information from another species. Sensors for light, temperature, $\mathrm{pH}, \mathrm{UV}$ or other physical parameters can be used as triggers for biosafety systems. Avoiding issues of vertical gene transfer (VGT) through cell division, cell free systems seem to be a well suited biosafety approach. In combination with xenobiology, cell free systems could efficiently minimize the risk of HGT and VGT. Finally, we aim to describe the design of an optimized biosafety system by integration of different mechanisms, which consequently could be referred to as a synthetic biosafety system [51].

\section{Auxotrophy}

One of the earliest methods applied for biocontainment was auxotrophy, introduced either by random mutation or targeted engineering [52]. In respect to biosafety, auxotrophic organisms are not able to synthesize one or more compounds required for survival or replication, so the missing components must be provided externally [53]. Therefore, the organism cannot survive outside a controlled environment, such as a bioreactor. Research on auxotrophic strains dates back to 1941, when Beadly and Tatum characterized a strain of Neurospora sitophila without pyridoxine [54]. The first construction and application of an auxotroph E. coli strain for biosafety reasons was developed in 1977 by Curtiss and colleagues [52], who developed the strain $\chi 1776$, which requires diaminopimelic acid (DAP) and thymine or thymidine 
for growth. Indeed, many prominent laboratory E. coli strains are auxotrophic mutants [55]. Over the years, auxotropy-based systems have been developed further and successfully improved with regards to reducing the escape frequency [53] (the escape frequency describes the probability of an organism bypassing the containment measures and is usually determined by quantification of escape mutants found in a defined cell number [56]), with an increasing number of studies reporting escape frequencies (Table 2) below the detection limit (e.g. [57, 58]). Auxotrophy-based systems are manifold in nature, with different hosts (e.g. E. coli or other bacteria, plants, or fungi) and various possible dependencies, most commonly for amino acids or vitamins.

\section{Strains auxotrophic for proteinogenic amino acids}

The dependency of engineered organisms on one or multiple naturally occurring amino acids has been used in many studies to improve biosafety via containment or replacement of problematic functions. A prime example for the latter is the substitution of antibiotic resistance markers on plasmids. These standard tools in genetic engineering traditionally contain an antibiotic resistance gene as a selection marker, which further ensures plasmid maintenance. This is potentially hazardous, as the resistance genes could be released into the environment [59-61]. As an alternative to antibiotic selection markers, the auxotrophic E. coli strain M15 carries an inactive glyA gene, which is necessary for intracellular glycine synthesis [59]. The antibiotic-free expression system utilizes the M15 strain with a constructed plasmid providing the $g l y A$ gene and thereby preventing plasmid loss. A similar approach was used in the modified E. coli strain JM83 auxotrophic for proline and a complementing vector supplying the proBA genes necessary for the proline biosynthetic pathway [62]. Antibiotic resistance-free systems have also been used as a safe method for vaccine production and are not limited to $E$. coli. An example is the cattle vaccine Brucella abortus mutant strain (RB51) with non-functional 3-isopropylmalate dehydrogenase $(l e u B)$, which is essential for biosynthesis of leucine [60]. By adding a plasmid carrying the wild type leuB to the leucine-auxotrophic strain, the B. abortus strain is able to survive and the corresponding plasmid is maintained due to selective pressure. The resulting system is a biologically safe vaccine system, as the $B$. abortus mutant strain induces immune responses through a plasmid containing the gene encoding the desired antigen, but no antibiotic resistance gene, which could potentially spread to the microbial flora of an animal. In 2012, a system was engineered that supported the usage of the duckweed Lemna for the production of vaccines and therapeutics [63]. An avian influenza vaccine antigen was successfully expressed in the system containing an isoleucine auxotroph strain of Lemna. Particularly, threonine deaminase expression necessary for the isoleucine biosynthesis had been inactivated in a system containing an isoleucine auxotroph strain of Lemna, which was then supplemented with isoleucine to enable growth.

\section{Strains auxotrophic for other natural components}

A different biosafety approach is to prevent an organism from building a cell wall by means of engineered auxotrophy. For example, D-alanine is an essential component of the peptidoglycan layer, since it is one of the molecules necessary for the cross-linkage of the polysaccharide chains $[64,65]$. L-alanine can be converted to D-alanine by two different alanine racemases in $E$. coli, one being encoded by $a l r$, the other one by $d a d X$ [66]. In Corynebacteriaceae, only the alr gene is present, which was deleted in Corynebacterium glutamicum [65] and Mycobacterium smegmatis [67,68]. While Tauch et al. [65] successfully created a D-alanine auxotroph and subsequently used a plasmid-borne alr gene to replace an antibiotic resistance marker, Chacon et al. [67] found that M. smegmatis mutants with inserted inactivated $\mathrm{D}$-alanine racemase gene were still able to grow without supplied D-alanine.

Focusing on the aspartate semialdehyde dehydrogenase (asd) gene, an antibiotic resistance gene free plasmid Salmonella enteritidis "ghost" (i.e. an empty cell envelope possessing intact bacterial surface structures and integrated antigen proteins) has been developed as a safe vaccine against infectious diseases in chicken [69]. The strategy was to delete the asd gene, which encodes aspartate ß-semialdehyde dehydrogenase (Asd), an enzyme located at the root of biosynthesis of the aspartate-derived amino acids lysine, threonine and methionine. Asd is also involved in forming the precursor for the production of diaminopimelic acid (DAP), which in turn is necessary to build the cell wall structures in most bacteria. As a complement, a plasmid carrying the asd gene and a lysis system (pJHL101) for production of the "ghost" was constructed. The resulting strain was tested as a vaccine in chickens and shown to elicit substantial immune responses [69].

Additionally, an auxotrophic E. coli strain has been engineered by inactivating the chromosomal quinolinic acid phosphoribosyltransferase (QAPRTase) gene, a key enzyme in the nicotinamide adenine dinucleotide (NAD) synthesis pathway [61]. Thus, an antibiotic-free plasmid selection system has been created by complementing the system with a plasmid containing the QAPRTase gene of the mouse. The resulting antibiotic-free selection system was the first to use a vertebrate gene and the strain can be maintained in complex (LB) or minimal media.

Hirota et al. developed a novel biocontainment strategy based on a dependency on phosphite [70]. By disrupting all endogenous $P_{i}$ and organic $P_{i}$ transporters 
and by producing the transporter $\mathrm{HtxBCDE}$, as well as HtxA and PtxD, the researchers engineered an E. coli strain dependent on phosphite or hypophosphite. HtxBCDE, a transporter from Pseudomonas stutzeri WM88, is capable of transporting phosphite and hypophosphite but not phosphate. Production of the hypophosphite dioxygenase HtxA and of the phosphite dehydrogenase PtxD allowed utilization of hypophosphite and phosphite as sole sources of $\mathrm{P}_{\mathrm{i}}$. When tested on non-permissive growth medium, no escape mutants were detected after 21 days. An escape frequency of $1.94 \times 10^{-13}$ was achieved, which is extremely low compared to other biocontainment approaches (Table 2).

Examples of natural containment systems also include a strategy to treat inflammatory bowel disease in humans by a genetically modified Lactococcus lactis strain. The strain was altered by replacing thy $A$, the gene encoding thymidylate synthase, which is essential for growth of the bacterium, with a human interleukin-10 gene [71]. The resulting strain produces human interleukin-10, which is used as a therapeutic for inflammatory bowel disease. Furthermore, it is dependent on thymidine or thymine for survival, thus providing a biologically contained system for clinical treatment in humans. The strain has been successfully tested in a clinical trial [72]. Specifically, no severe side effects were detected in the patients, and the thyA-deficient organism was found to be unable to replicate without proper supplementation.

To increase performance, auxotrophic systems can be combined to engineer strains with multiple auxotrophies in order to further improve containment capability, such as the synthetic E. coli auxotrophs with liganddependent essential genes (SLiDE) [73], which uses a mutation approach demonstrated by the Karanicolas lab [74]. The resulting strains can only survive if they are supplied with the low-cost ligand benzothiazole, enabling the growth through the gain-of function of an essential protein in which an aromatic amino acid residue was mutated to a glycine. For further improved containment, multiple SLiDE alleles were incorporated in $E$. coli. While escape frequencies (Table 2) for strains with a single SLiDE allele ranged between $8 \times 10^{-4}$ and $3 \times$ $10^{-9}$, incorporating two alleles resulted in improved escape frequencies of up to $5 \times 10^{-10}$, and building in three SLiDE alleles lead to undetectable escape frequencies below $3 \times 10^{-11}$ [74].

Still, even combining several auxotrophies for natural compounds required by the organisms cannot overcome a major drawback inherent in this approach: The necessary compounds can potentially occur in the natural environment, compromising the safety mechanism. Hence, compounds which do not naturally occur in the environment have been considered as a complement for auxotrophs.

\section{Evaluation of auxotrophic strains for biosafety purposes}

In conclusion, auxotrophic GMOs are simple and cost-efficient biocontainment systems with a variety of possible applications. Complementing substances can be provided via the growth media, and multiple auxotrophies further reduce escape risks. However, auxotrophic systems suffer from substantial drawbacks, such as possible metabolic cross-feeding, toxic overexpression, and loss of function due to decreased selection pressure in a heterogeneous natural environment (for a summary see [75]). Therefore, instead of relying on an auxotrophy system alone, they are often part of a complex multilayered biosafety system, such as SafeGuard [76] or GeneGuard [32]. In the GeneGuard plasmid system (Fig. 1), auxotrophies based on translocation of the essential genes thyA or dapA to a plasmid location were combined with a conditional origin of replication and toxin-antitoxin system to engineer a host-plasmid mutual dependency [32].

\section{Auxotrophy systems in the iGEM competition}

Compared to their prominence in research, the implementations of auxotrophic strains in iGEM projects have been relatively rare, which is in part due to the fact that the iGEM foundation does not collect and provide such genetically modified strains, making it necessary for the iGEM teams to either create them themselves or obtain them from other sources.

A successful implementation of an auxotrophic strain for a biosafety system had been accomplished by team Bielefeld-Germany 2013 [77]. The team created a biosafety system composed of three independent layers, one of which being a D-alanine auxotrophy, established by deleting both racemase genes, alr and $d a d X$. The team showed that cells grown on media without D-alanine supplemented or not carrying a plasmidbound alanine racemase (BBa_K1172901) were unable to grow. Bielefeld-CeBiTec 2014 [78] adapted the system for an antibiotic-free selection, hence eliminating the problems resulting from extensive use of antibiotics in laboratories. This underlines the multifaceted possible applications of auxotrophies.

Other teams have conceptually considered auxotrophic strains for their projects, whilst not implementing these themselves. Team BYU Provo 2014 [79], for example, worked with the bacterium Nitrosospira multiformis in the context of wastewater treatment and identified serine as being abundant in the bioreactor/sedimentation tank, but not in the waterways. Therefore, it was proposed that deletion of serA from $N$. multiformis would result in a dependency for serine, hence making growth outside the bioreactor or sedimentation tank improbable.

The biosafety system for Synechocystis sp. suggested by team Amsterdam 2015 [80] is based on an arginine and 


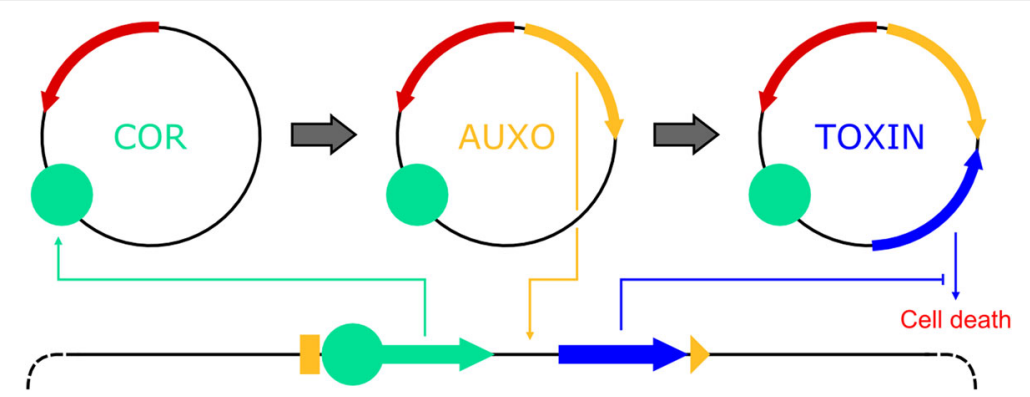

Fig. 1 GeneGuard as an example for a modular, multilayered biosafety system [32]. The plasmid system uses conditional origins of replication, auxotrophies and TA systems. Replication initiators are provided in trans by the host, minimizing the risk of replication in unintended hosts. The host lacks the essential genes thyA or dapA which are located on the plasmid, making the plasmid essential for cell survival. As a third layer the TA systems Epsilon-Zeta or Kis-Kid were used to kill the cells after losing the plasmid

proline auxotrophy. To implement the auxotrophies, deletion of $\operatorname{argH}$ for arginine and proC for proline auxotrophy was proposed. Since the team could not finish the desired work in time, no results regarding the effectiveness of a combination of an arginine and proline auxotrophy are available.

\section{Kill switch: plasmid retention and cell destruction}

While auxotrophies prevent a continuous survival or replication of cells, biological kill switches are applied to prevent the survival of a cell immediately. Typically, these biosafety systems make use of bacteriolytic toxinantitoxin systems (TA) of different complexities. So far, five different types of TA systems have been identified and described in the literature [81].

Antisense RNA meditates the inhibition in type I systems $[82,83]$. Besides the sense strand transcription of the toxin gene, the sequence of the reverse strand is partially transcribed as well, leading to a complementary RNA called an antitoxin. This antisense transcript binds to the sense transcript and prevents the translation by blocking off the ribosome or by promoting the degradation of the mRNA, respectively [84, 85]. Famous examples of type I TA systems are hok-sok and similar systems like pndA-pndB and symR-symE [86-89].

Type I TA systems have not been commonly applied in the iGEM competition in the context of biosafety (Table 1). Most teams have integrated type I TA systems for plasmid maintenance and as an alternative for antibiotic resistance cassettes. Team NTU Taida 2012 [90] used the Hok-Sok homologue SrnB-SrnC (BBa_K817015) to ensure plasmid maintenance and to kill cells after plasmid loss. University of Maryland 2015 [91] investigated the ability to use Hok-Sok (BBa_K1783001) for antibiotic-free plasmid maintenance.

Type II systems are based on two genes that are usually adjacent, are oriented head to tail, and form an operon. Systems characterized as type II TA systems include $c c d A-c c d B$, kis-kid, parDE, phd-doc, mazE-mazF, and axe-txe [92-97]. The encoded toxin and antitoxin form a stable complex, inhibiting the toxin and thereby preventing the deleterious effects on the host cell. Furthermore, the toxin-antitoxin complex binds to the antitoxin-toxin promoter region and represses the transcription of the antitoxin and toxin genes [98-101]. Since the antitoxin is less stable than the toxin, a 'point of no return' can be reached under stress conditions, resulting in growth inhibition and, eventually, cell death [96, 97, 102, 103].

Several teams in the iGEM competition have tried to apply the principle of natural type II TA systems to synthetic biosafety systems (Table 1 ). Team Paris Bettencourt 2012 [104] used a Col E2 toxin and Col E2 antitoxin, encoded on two different plasmids (BBa_K914001, BBa_K914002). Two separate plasmids were used to allow directed degradation of the antitoxin plasmid through a dedicated restriction enzyme system, hence switching on the kill switch.

Team Wageningen UR 2014 [105] used a similar system based on two plasmids. The team applied a combination of the Kis-Kid (BBa_K1493601) and the Epsilon-Zeta (BBa_K1493603) systems to prohibit HGT. Therefore, while the Kis antitoxin and the Zeta toxin were encoded on one plasmid, the Kid toxin and the Epsilon antitoxin were encoded on the other plasmid, creating an interdependent system. In case one plasmid is transferred to a wildtype cell, the analogous antitoxin for the toxin featured on the plasmid is not present, thus killing the recipient.

Team UC Berkeley 2008 [106] used a type II TA system and combined it with a lysozyme (BBa_K112808). The team used holin and antiholin as the toxin-antitoxin pair under control of two separate promoters. While the antiholin is expressed constitutively, expression of the lysozyme and holin is controlled by an inducible promoter. As soon as holin forms pores in the inner membrane, the lysozyme can reach the periplasm and lyse the cell. This system was not designed by the team for biosafety purposes but could be easily adapted for that role. 


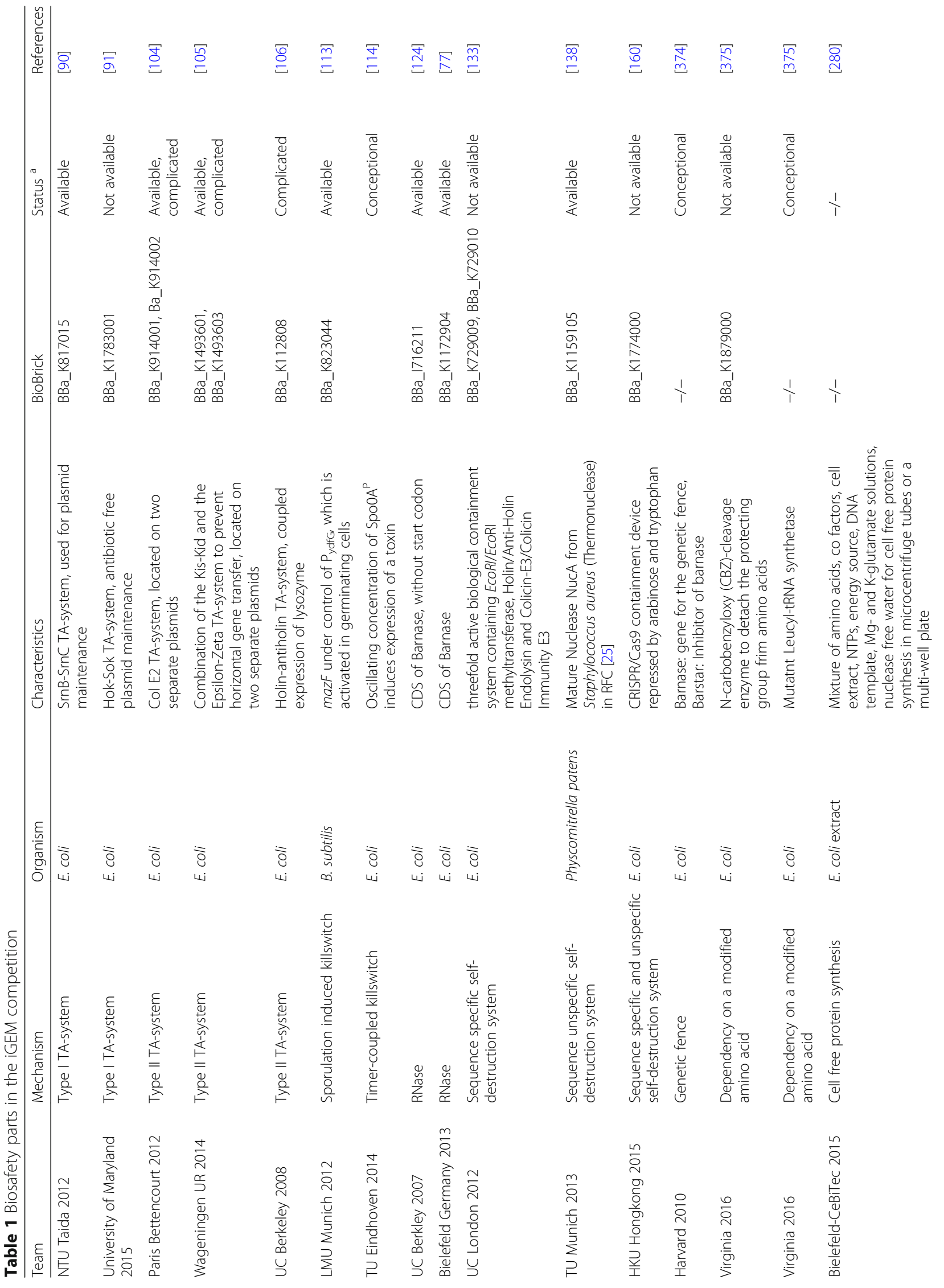




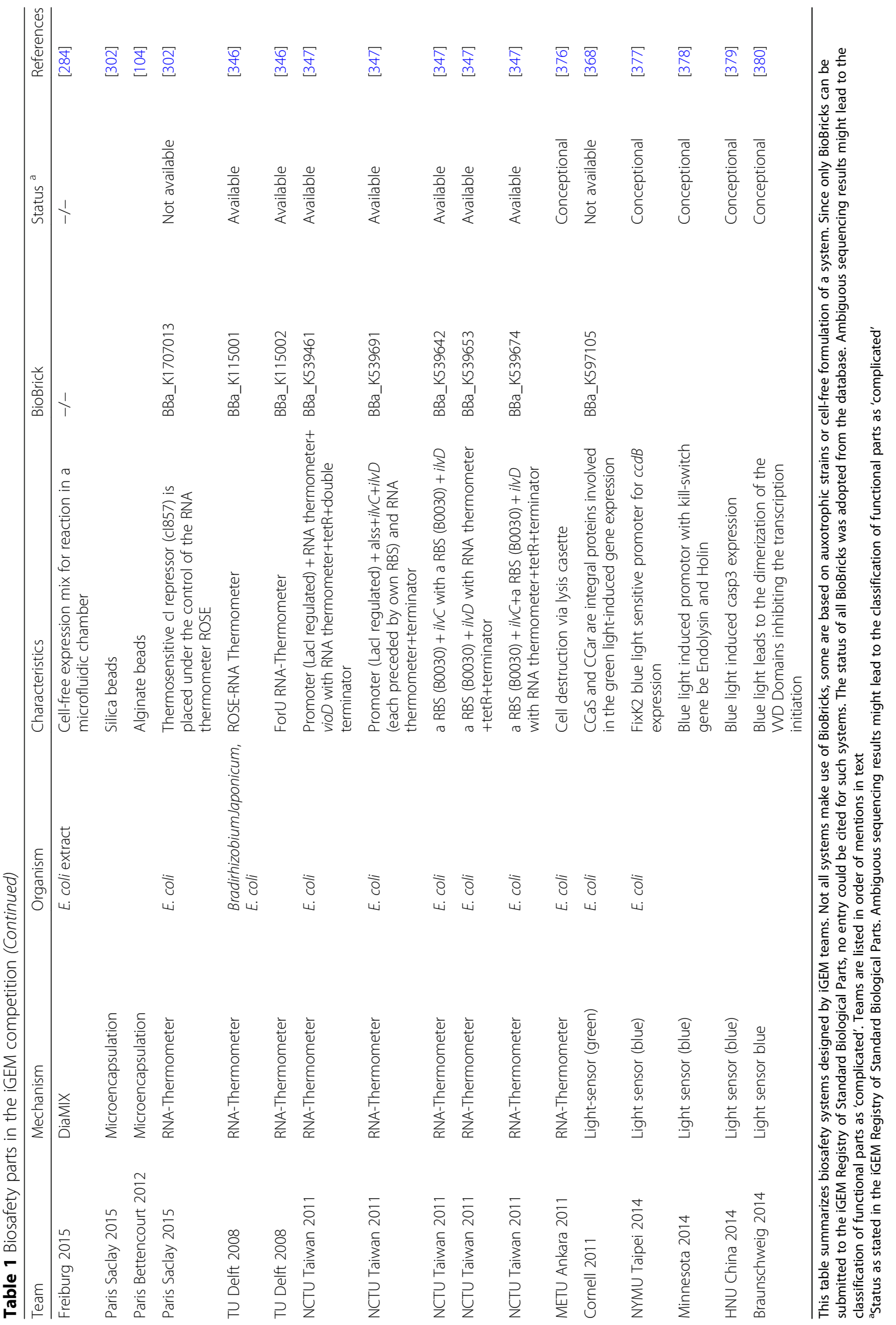


Type II TA systems have also been extensively applied outside of the iGEM competition. Stirling and colleagues built two evolutionary stable kill switches to control the environment in which a genetically engineered strain of E. coli can survive [107]. Their "essentializer" kill switch is based on a bi-stable cI/Cro memory switch. Cell death is induced by loss of the memory switch. The "cryodeath" kill switch was built around a cold-inducible promotor, allowing growth at $37{ }^{\circ} \mathrm{C}$. At a temperature of $22{ }^{\circ} \mathrm{C}$ and below, a survival ratio of less than $10^{-5}$ was reached (Table 2). Both kill switches were engineered using the type II TA system CcdB-CcdA [107].

While type I and type II systems are based on interactions of two components of the same kind to mediate inhibition either via RNA or protein toxin-antitoxin complexes, type III systems are based on the interaction of antitoxin RNA with the toxin protein [108, 109]. To our knowledge, only one example for a type III TA system has been identified so far: ToxIN from Erwinia carotovora subsp. atroseptica which acts as an abortive infection system $[108,110]$. No iGEM team has applied this type III TA system as a biosafety system yet.

Recently, type IV and V TA systems have been identified. In type IV systems like yeeU-yeeV, the antitoxin and toxin do not form a complex. Instead, the antitoxin acts as an antagonist. While YeeV inhibits the assembly of FtsZ and MreB filaments, YeeU promotes the reaction, hence counteracting the toxicity of YeeV [111]. Type V TA systems like ghoS-ghoT also function without formation of a toxinantitoxin complex. GhoS possesses a sequence-specific endoribonuclease activity, cleaving the GhoT mRNA, thereby inhibiting formation of the toxin protein [112].

Many teams in the iGEM competition used toxins under control of specific promoters without a corresponding antitoxin to create biosafety systems (Table 1). Team LMU Munich 2012 [113] created a kill switch for Bacillus subtilis to kill germinating spores (BBa_K823044): the team placed mazF under control of $\mathrm{P}_{\mathrm{ydfG}}$. This promoter is activated by the sigma factor of RNA polymerase ECF41 which is produced during sporulation, thus the team created a sporulation-induced kill switch. Team TU Eindhoven 2014 [114] proposed a timer-coupled kill switch based on the oscillating concentration of phosphorylated SpoOA protein (Spo0AP). Once a certain concentration of Spo0AP is reached, expression of a toxic gene under the control of a Spo0AP-sensitive promoter will be induced, leading to cell death.

The ribonuclease $b a$ of Bacillus amyloliquefaciens (barnase) and the corresponding inhibitor barstar are sometimes referred to as a toxin-antitoxin system when combined [95]. Whilst the organization of barstar and barnase genes differ from the organization of natural toxin and antitoxin systems, the combination of barnase and barstar exhibits many similarities to natural TA-systems. For biosafety applications, the inhibitor gene barstar is usually integrated in the chromosome and constitutively expressed. Barnase is encoded on a plasmid, preferably under control of an inducible or repressible promoter. Furthermore, the fusion of the barnase to secretion signals like that of PhoA allows the

Table 2 Escape frequencies of selected biosafety systems

\begin{tabular}{|c|c|c|c|}
\hline Name of the System & Type of System & Escape Frequency & Reference \\
\hline SLiDE, single allele & Auxotrophy & $8 \times 10^{-4}$ to $3 \times 10^{-9}$ & [69] \\
\hline SLiDE, two alleles & Auxotrophy & $5 \times 10^{-10}$ & [69] \\
\hline SLiDE, three alleles & Auxotrophy & $<3 \times 10^{-11}$ & [69] \\
\hline Thymine/Thymidine auxotrophy & Auxotrophy & Below detection limit & {$[71,72]$} \\
\hline Artificial Phosphite Dependency & Auxotrophy & $1.94 \times 10^{-13}$ & [70] \\
\hline Single ncAA auxotrophy & Auxotrophy/Xenobiology & No escape mutants in $>5 \times 10^{11}$ cells & [381] \\
\hline Triple ncAA auxotrophy & Auxotrophy/Xenobiology & $6.41 \times 10^{-11}$ & [57] \\
\hline $\mathrm{CcdB}$ & Kill switch & $\sim 10^{-3}$ & [28] \\
\hline Cryodeath & Kill switch & $<1$ in $10^{5}$ after 10 days in vivo & [107] \\
\hline Deadman & Kill switch & Below detection limit & [28] \\
\hline Passcode & Kill switch & Below detection limit & [28] \\
\hline CRISPR mediated DNA degradation & DNA destruction & Viable cells reduced by a factor of $10^{8}$ & [152] \\
\hline Thermoinduced DNA degradation & DNA destruction & $2 \times 10^{-5}$ & [135] \\
\hline GeneGuard & Combinatorial system & Below detection limit & [32] \\
\hline SafeGuard & Combinatorial system & $<1.3 \times 10^{-12}$ & [76] \\
\hline
\end{tabular}

In general, the combination of several systems reduces the probability for random mutagenesis to disarm the biosafety system and for cells to bypass the biosafety system. Therefore, multilayered systems like Passcode, Deadman or GeneGuard act as great examples for complex biosafety systems that achieved very low escape frequencies. Engineering artificial auxotrophies, such as an artificial phosphite dependency, can also act as potent biosafety systems, as shown by Hirota et al. 
secretion into the periplasm [115-121]. Secreted barnase can be toxic to bacteria in the proximity of the producing cells if they do not express the inhibitor barstar, but the exact mechanism remains unknown [120, 121]. In combination with another biosafety systems which represses the expression of barnase through arabinoseinducible promoter like $\mathrm{P}_{\mathrm{BAD}}$, the expression of barnase can be induced if that biosafety mechanism fails, hence killing the host cell $[122,123]$.

Many iGEM teams employed a barnase system, but only few used it solely for biosafety purposes. Team UC Berkley 2007 [124] was the first to use the barnase (BBa_I716211) under control of the promoter $\mathrm{P}_{\mathrm{BAD}}$ to induce self-destruction.

Team Bielefeld-Germany 2013 [77] improved the barnase based biosafety system by using it in combination with a D-alanine auxotrophic strain $(\Delta a l r)$ as a two-part system (BBa_K1172904). The first part contains the repressor for the promoter of the second part $\left(\mathrm{P}_{\mathrm{BAD}}\right)$ and the alanine racemase, both under the control of a rhamnose-inducible promoter $\left(\mathrm{P}_{\mathrm{Rha}}\right)$. The second part contains the $\mathrm{P}_{\mathrm{BAD}}$ promoter and barnase itself. Should the first promoter remain inactive due to auxotrophy failures, barnase is expressed and will lead to cell death.

Team Valencia UPV 2014 [125] aimed to develop a biosafety module to prevent the spread of genetic material in plant seeds. The concept was to use barnase (BBa_I716211) in combination with the tapetum-specific promoter TA29. Due to time restrictions, this concept could not be tested.

More complex kill switches like Deadman and Passcode (Fig. 2) were recently developed [28]. Both systems are based on one or multiple synthetic molecules necessary for the cell's survival. The Deadman switch is based on mutually reinforcing feedback loops and uses anhydrotetracycline (ATc) as the synthetic molecule, which prevents inhibition of lacI transcription by TetR. LacI inhibits transcription of the toxin, hence preventing cell death. Additionally, LacI weakly represses tetR and strongly represses transcription of the protease Mf-Lon, which degrades LacI. The group also studied the possibility to use Mf-Lon to degrade an essential protein and found that a combination of the restriction endonuclease EcoRI (the toxin) and the degradation of the essential protein MurC results in survival rates (Table 2) below the limit of detection. The Passcode switch uses three independent 'input signals' (galactose, cellobiose, IPTG). Input A (galactose) inhibits GalR-LacI, while input B (cellobiose) inhibits CelR-LacI. Both GalR-LacI and CelR-LacI can bind the LacI-ScrR operator, thus inhibiting expression of LacI-ScrR. Expression of the toxin is repressed by LacI-ScrR, which can be inhibited by input

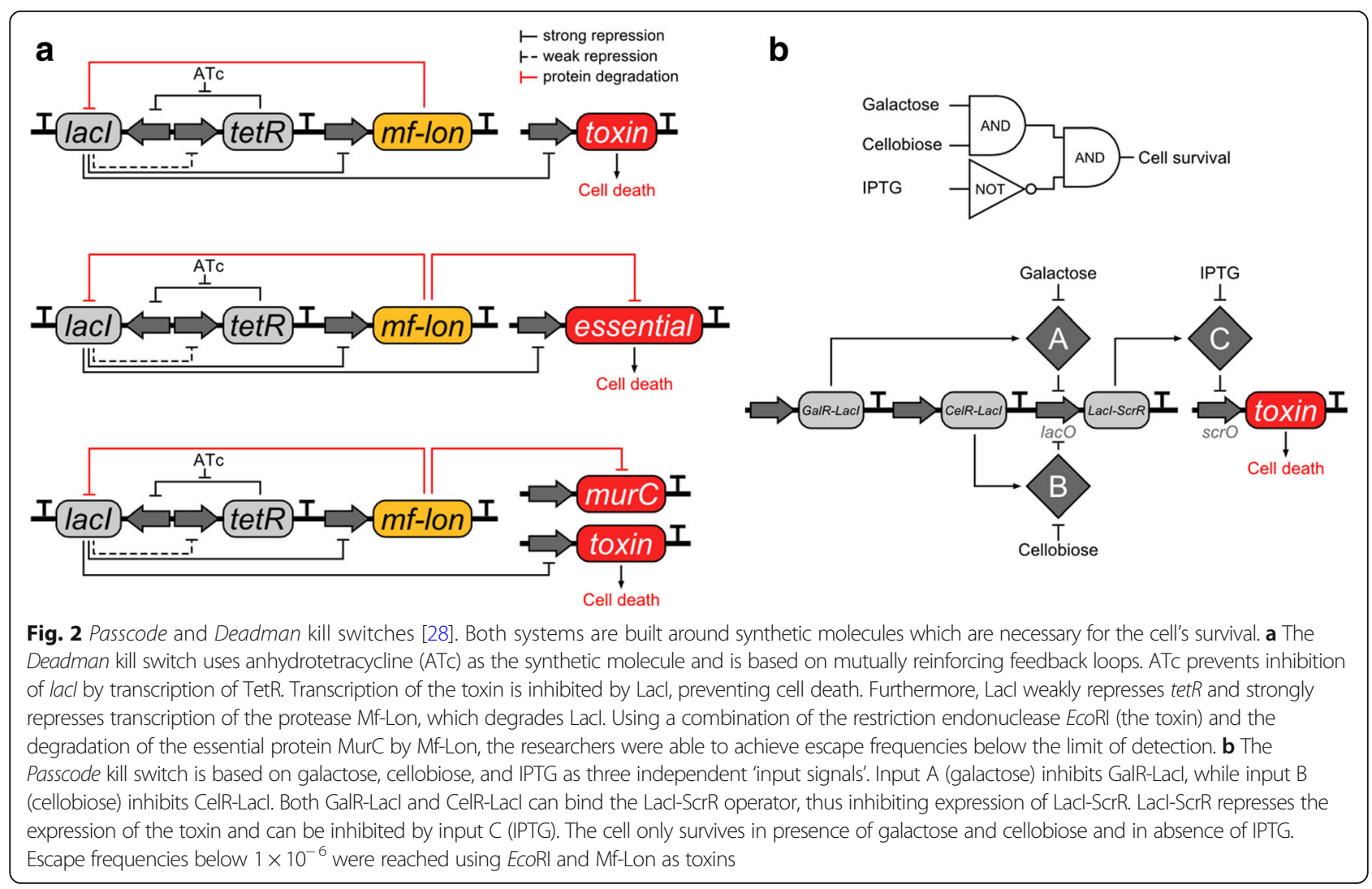


C (IPTG). Therefore, the cell only survives in presence of galactose and cellobiose and in absence of IPTG. Using again EcoRI and Mf-Lon as toxins, cell survival ratios below $1 \times 10-6$ were reached.

\section{Kill switch: DNA destruction}

Kill switch systems for GMOs are widely used as biosafety systems. But, depending on the TA type (I to V) used, genetic information can potentially be released and spread through HGT [26, 32, 126, 127]. Therefore, genetic information has to be released, taken up by another organism, maintained and expressed [26]. If the uptake of this genetic information has an evolutionary advantage for the recipient cells, for example the information for an antibiotic resistance gene, it is likely to remain in the genome. Thus, genetic incorporation can lead to resistance to antibiotics or other advantages for recipient cells. Adapting a combination of toxin-antitoxin systems and self-destruction systems prevents the spread of recombinant DNA by the degradation of nucleic acids, while the targeted cells are killed. Therefore, self-destruction can be seen as a special case of a kill switch system. All systems based on destruction of nucleic acids can be loosely subdivided into three systems depending on the sequence specificity of used systems: (i) specific systems are based on nucleases which hydrolyze nucleic acids at sequence specific sites known as restriction sites, (ii) unspecific systems utilize nucleases which hydrolyze DNA and are not sequence specific and (iii) a third system which is a combination of sequence specific and unspecific parts.

Specific systems of self-destruction are toxin-antitoxin systems based on nucleases applied to kill cells with minor risk of DNA leakage. Usually, the nuclease (toxin) is encoded on the plasmid, while the nuclease-methyltransferase (antitoxin) is encoded on the chromosome. Both nuclease and nucleasemethyltransferase compete for the same sequence-specific DNA recognition site. Thus, expression levels between this toxin-antitoxin gene pairs need to be adjusted. The toxin is constitutively expressed and the expression of the antitoxin is induced, for instance, by using an anhydro-tetracyclin-responsive promoter [76]. When expressed the nuclease-methyltransferase methylates certain nucleobases at the recognition site, hence preventing cleavage of the DNA by the nuclease. This modification prevents digestion of the cell's own DNA. A known toxin-antitoxin system is EcoRI/EcoRI methyltransferase [128-132]. Destruction of the genomic information is initiated by switching off the expression of the antitoxin-methyltransferase. Even if HGT occurs, the recipient cells are unlikely to counteract the nuclease due to the lack of methyltransferase.

The team University College London 2012 [133] used the $E c o$ RI/EcoRI methyltransferase system in their novel threefold active biological containment system (Table 1) in combination with holin/anti-holin endolysin and colicin-E3/colicin Immunity E3 (BBa_K729009, BBa K729010). The aim was to minimize HGT via bacterial conjugation using this new system.

At the end of the last century, genes encoding sequence specific restriction nucleases under different promoters were characterized for inducible degradation of DNA [134]. Stephen Cuskey performed preliminary tests with EcoRI under control of an inducible promoter as mentioned by Molin et al. 1993 [134]. Results showed that growth was reduced due to a high base level of gene expression without induction. Double strand breaks caused by EcoRI at a high rate are responsible for slow growth, as the repair mechanisms are insufficient to fix them [134].

Nonspecific nucleases, which introduce single strand breaks, combined with an inducible promoter, a ribosome binding-site, and a start codon, appeared to be better candidates [134, 135]. Molin and Ahrenholtz both tested the extracellular nuclease of Serratia marcescens $[134,135]$. The nucA gene encodes a 266 amino acid long polypeptide with a 21 amino acid long N-terminal leader peptide [136, 137]. In both cases, the nucA gene without the leader peptide was under control of an inducible promoter lac and lambda $p_{L}$, respectively $[134,135]$. NucA is one example for an unspecific self-destruction system.

The team TU Munich 2013 [138] used the thermonuclease NucA of Staphylococcus aureus (BBa_K1159105) to degrade DNA of a genetically modified moss (Table 1 ). The nuclease (BBa_K1159111) is bound to the membrane with a transmembrane domain (BBa_K1159315) and contains a TEV cleavage site as well as a SV40 nuclear localization signal (NLS) (BBa_K1159303). After PhyB (BBa_K801031) is activated with red light, it binds either protein PIF3 (BBa_K1159103) or PIF6 (BBa_K1159104). This binding initiates the assembly of the $\mathrm{N}$ - and C-terminal split TEV protease which in turn cleaves the TEV cleavage site thus releasing the nuclease; this is translocated into the nucleus where the DNA is degraded.

Team NTU-LIHPAO-Taiwan 2015 [139] also used the thermonuclease NucA of S. aureus (BBa_K1159105) under control of a lambda cl-regulated promoter (BBa_R0051) to degrade DNA, thus killing Lactobacillus case $i$ if the $\mathrm{cl}$ protein (BBa_C0051) concentration decreased below a certain threshold. The expression of $c l$ is controlled by the lac-promoter and therefore regulated by lactose and glucose. The whole system is hypothetically designed to inhibit HGT from L.casei to bacteria in the human gastrointestinal tract while controlling the proliferation of the cells.

While sequence specific and unspecific systems may be of use in general self-destruction, the expression 
controls can be leaky leading to a baseline expression which is damaging to the cells even if they are contained. Also, both systems are not able to target specific sites which encode vital enzymes and proteins and are thus inefficient at mediating cell death. A combinatorial system of sequence specific and unspecific parts can be adapted for high-efficiency, easily controllable biosafety.

A self-destruction system which is based on sequence specific and unspecific parts is the clustered regularly interspaced short palindromic repeats (CRISPR)/CRISPR associated (Cas) system - the RNA-mediated adaptive defense systems of bacteria [140-144] Shortly after its discovery, it was adapted for genome and transcriptome editing [145-149]. The sequence-specific CRISPR is used to guide the sequence-unspecific Cas nuclease to its target, thus making this system highly regulated without the risk of uncontrollable cleavage. Employing the same mechanism on essential and non-essential genes enables controlled degradation to prevent HGT in the event of an unintentional release [150-152]. In nature three types of CRISPR/Cas systems are specified with variations concerning target and mechanism: type I systems cleave and degrade DNA; type II systems solely cleave DNA; and type III systems cleave DNA and RNA [153]. For the purpose of self-destruction, the type I system is well suited and frequently employed [151, 152]. Type I and type II systems are dependent on (i) CRISPR RNA spacer and target protospacer sequence complementarity as well as (ii) the protospacer-adjacent motif (PAM) [154-157]. By combining different Cas proteins and PAM sequences, a broad range of applications can be enabled influencing the kinetics of target degradation [151-153, 158]. Type III systems also require spacerprotospacer complementarity and specific sequences in the neighborhood of the protospacer [159]. Specific ON and OFF states of expression should be defined when employing the CRISPR/Cas mechanism for degradation of DNA to ensure induction of expression of both components in response to specific environmental changes [152].

Team HKU Hongkong 2015 [160] designed a CRISPR/ Cas9 system with a specific sgRNA (BBa_K1774000) to target the DNA polymerase III alpha subunit (dnaE) thus inhibiting replication of the bacteria. The OFF state was defined by the availability of arabinose and tryptophan. Arabinose induced the expression of $\operatorname{araC}$ which in turn induces the expression of $c l$ under control of the $\mathrm{P}_{\mathrm{BAD}}$ promoter, thus inhibiting the $\mathrm{P}_{\mathrm{R}}$ promoter and the expression of cas9. If available, tryptophan binds to a repressor which in turn blocks the trp promoter and thus sgRNA expression. In the $\mathrm{ON}$ state, arabinose and tryptophan are not available, which mimics a possible physical containment breach. A lack of transcriptional repression results in the formation of Cas 9 and the
sgRNA, which can destroy the gene of DNA polymerase III alpha subunit.

Given that kill switches are prone to inactivating point mutations [161], especially when constitutively expressed, researchers have developed new biosafety systems that do not harm the host, potentially minimizing the risk of unintended proliferation caused by mutagenesis. Jia and colleagues developed an orthogonal ribosome biofirewall, consisting of an activation circuit and a degradation circuit [162]. The activation circuit, a genetic AND gate, utilizes an orthogonal ribosome to activate an encrypted pathway based on specific environmental inputs. The genes encoding the orthogonal ribosome can be degraded by the degradation circuit, a genetic NOT gate, based on a change of the environmental inputs. This elegant system not only minimizes the burden on the host, given that the toxin I-SceI is not constitutively expressed, but also makes expression of the genes of interest dependent of the presence of the orthogonal ribosome. Therefore, even if HGT occurs, expression of the genes of interest is prevent due to the lack of an orthogonal ribosome. The plasmid containing the genes for the orthogonal ribosome is digested in absence of specific environmental inputs. This work highlights how conditional degradation of genetic information can be combined with genetic encryption to create an adaptable and tightly regulated biofirewall for microbial biocontainment [162].

\section{Xenobiology-based containment}

The term 'xenobiology' has experienced significant semantic shift over the last few decades [163-165]. Kubyshkin et al. define xenobiology as an approach to expand the framework of natural chemistries with non-natural building blocks in living cells to accomplish artificial biodiversity [50]. Therefore, one key aspect of xenobiology is the search for alternative chemistry for nucleic acids, proteins and other cellular components and functions. Xenobiological systems are also referred to as orthogonal systems or chemically modified organisms (CMOs) [50, 163]. Current biosafety systems are meant to kill cells once they escape from the assigned environment, leaving their recombinant DNA freely available in nature [166]. An orthogonal system prevents HGT [167] through transduction [168], conjugation, and transformation, as reviewed by Davison [169]. As a consequence, wild type cells are unable to integrate and maintain XNA into their genome and cannot handle the incorporation of ncAAs $[170,171]$. Thus, XNA can potentially become a powerful biosafety tool by preventing HGT as it should not be read properly by wild type DNA processing enzymes like DNA and RNA polymerases [164].

The classification of xenobiology is not consistent. Some categorize it along with trophic and semantic 
containment for the prevention of metabolic and genetic exchange [171]. Giving this inconsistency, the following chapters are categorized according to the components that could be changed or alienated like the bases, backbone, leaving group, codons and amino acids.

\section{Synthetic bases - building up Xeno-DNA}

During the emergence of recombinant DNA technology, a plasmid containing DNA of another species was described as Xeno-DNA (XNA) [20]; the modern perception of XNA describes non-canonical DNA building blocks or substantial modifications of the natural structure, such as alternative pairing nucleotides, modified sugars, or backbones $[165,172,173]$. XNA could be considered a genetic firewall masking the encoded information from nature [163]. The main approach of designing XNA is to replace or extend the standard genetic code comprising four naturally occurring nucleotides in the DNA. There are various sophisticated approaches to identify potential replacements for the four canonical bases [174-181]. Nevertheless, advances in XNA technology have to fulfill some requirements to establish stable products in vivo [172, 182].

First experiments extended the four nucleotide alphabet by replacing thymine with 5 -chlorouracil in $E$. coli over a period of 25 weeks [183, 184]. Other approaches expanded the genetic alphabet by introducing the two artificial bases dP (2-amino-8-(1'- $\beta$-D-2'-deoxyribofuranosyl)-imidazol[1,2- $\alpha]-1,3,5$-trizan-4(H)-one), and $\mathrm{dZ}$ (6-amino-5-nitro-3-(1'- $\beta$-D-2' -deoxyribofurano-

syl)-2(1H)-pyridone) [185]. These artificial bases pair with three hydrogen bonds but vary in the pattern of donor and acceptor groups. A Taq DNA polymerase was modified to accept the new ATCGPZ-DNA, resulting in a retention rate of $98.9 \%[186,187]$. Moreover, a $\mathrm{T} 7$ RNA polymerase and a reverse transcriptase were developed for an RNA product containing $\mathrm{P}$ and $\mathrm{Z}$ [188]. The six nucleotide genetic alphabet will lead to DNA with a B-form as well as an A-form, with the major groves being $1 \AA$ wider than the natural G:C pair [189].

Interestingly, the concept of DNA can be extended beyond bases and pairing through hydrogen bonds. For example, pairings dependent on metal ion coordination [190-192] or hydrophobic interactions [193] were explored recently. Two promising candidates using hydrophobic interactions are d5SICS - dMMO2 and d5SICS-dNaM, which allowed transcription [193]. The first demonstration in E. coli was based on one plasmid encoding the nucleoside triphosphate transporter for $\mathrm{dNaM}$ and d5SICS and the other plasmid encoding a gene sequence using the extended genetic code [194]. Uptake of the synthetic bases as well as a stable plasmid replication over 24 generations was demonstrated [194]. In 2017, the Romesberg group presented a new version of their semi-synthetic organism. The most important advances were an optimized transporter with improved uptake of unnatural triphosphates and better retention of XNA with dNaM-dTPT3. Furthermore, they used a CRISPR-Cas system to eliminate plasmids that lost the XNA [177].

Besides expanding the alphabet of canonical DNA, XNA provides the opportunity to change the general topology. For example, benzo homologation provides the opportunity to expand the physical DNA size. The benzo expansion of pyrimidines to create $\mathrm{dxT}$ and $\mathrm{dxC}$ results in expanded DNA (xDNA), with the size increasing about $2.4 \AA$ and the helix becoming more thermally stable $[195,196]$. Stable replication of a plasmid containing up to eight $x$ DNA bases in a GFP encoding sequence as well as expression of the altered $g f p$ gene was demonstrated in E. coli [197]. By further changing the vector of extension, wide DNA (yDNA) can be obtained [198], although stable replication of this DNA type is problematic [199].

Use of XNA often necessitates synthetic or evolved proteins that allow for replication, transcription, and DNA packaging of the XNA. All presented examples depend on supplementation of the non-canonical nucleotides. This auxotrophy is a potent biosafety mechanism, which does not just prevent an uncontrolled growth of the engineered cells in the environment, but also protects the encoded information from spreading through HGT [163, 171].

\section{Alternative XNAs: modifying backbone or leaving group}

Besides the incorporation of non-canonical bases, experiments to engineer the DNA backbone by integrating substitutes for deoxyribose and ribose have been performed. For biosafety purposes, an altered backbone needs to meet the requirement to build a functional helix that does not interact with natural replication enzymes, instead requiring adjusted or even synthetic enzymes [172]. Some candidates for alternative backbone chemistries have previously been investigated as reviewed by Herdewijn and Marlière [172]; these examples include: hexitol nucleic acid (HNA) [200], threose (TNA) [201, 202], glycerol (GNA) [203], and cyclohexene (CeNA) [204]. A less complex method compared to the substitution of the whole genomic backbone is utilizing an orthogonal XNA episome which contains essential genes [172].

Besides the bases and the backbone, the third potential target to design XNA is alternating the leaving group of NTPs by replacing the pyrophosphate, such that they cannot be recognized by wild type polymerases. Studied analogues of ATP are methylene phosphonate, phosphoamidate [205], and thiophosphonate [206]. An alternative leaving group needs a high energy bond for the polymerization 
process. Studies on L-aspartate and L-histidine linked nucleotidemonophosphates showed that aspartic acid phosphoramidate derivates are working substrates for the HIV reverse transcriptase [207].

\section{Amber codon and non-canonical amino acids}

By systematically expanding the approach of auxotrophies based on xenobiotic compounds to utilizing a whole orthogonal genetic code, e.g. by means of xenobiology, the spread of recombinant sequences can also be prevented. There are three stop codons in the genetic code: ochre (UAA), opal (UGA) and amber (UAG) [208]. In $E$. coli, the amber codon is least common, with just over 300 occurrences (depending on the E. coli strain used). In 2013, Lajoie and colleagues coined the term genetically recoded organism (GRO) to describe organisms with an alternative genetic code [209]. Such GROs have been developed for enhanced biosafety compared to natural amino acid auxotrophs by engineering organisms to become auxotrophic for non-canonical amino acids (ncAAs) [58]. Rovner et al. constructed GROs based on E. coli without any TAG codon and the possibility to terminate translation at the UAA and UAG codons. After recoding the TAG codon to a sense codon for ncAAs by means of an orthogonal translation system (OTS), the recoded codon was incorporated into essential genes of the organism, thus making it dependent on ncAAs. Sixty variants of the auxotroph-GROs with varying growth and containment rates have been isolated, with one strain containing three recoded TAG codons maintaining stable growth, and undetectable escape frequencies over the course of 1 week or 20 days on solid or in liquid media, respectively. Changing the amber codon into a sense codon has been done multiple times by various groups [210-217], but results in the mistranslation of all genes using this stop codon. Therefore, the Church lab presented a GRO in which all 314 UAG stop codons were replaced by UAA stop codons. Deletion of release factor 1 (encoded by prfA), which recognizes UAG and UAA, then allows for recoding of the amber stop codon [218, 219]. Engineering a new aminoacyltRNA synthetase (aaRS) and corresponding tRNA leads to an orthogonal translation machinery required to harness the potential of an amber-free strain [220]. The non-canonical amino acid (ncAA) L-4,4'-biphenylalanine (BPA) had been integrated via the UAG stop codon of the GRO E. coli strain C321. $\Delta \mathrm{A}$ by Mandell et al.. This resulted in auxotrophs designed to be dependent on ncAAs [57]. Thus, the essential enzymes of the strain required BPA for core functions, such as translation. Additionally, in a proof-of-concept study, an E. coli strain BL21-AI (IY, lamB-immE3) containing the synthetic essential gene immE3 had been constructed, the translation of which depends on supplementation of the medium with the non-canonical amino acid 3-iodoL-tyrosine [221]. As an alternative to reassigning stop codons, it is also possible to reassign sense codons to ncAAs. In order to ensure proper functioning of the altered strain, rarely-used sense codons have been used, such as the codon AGG, which usually codes for arginine and has been reassigned to code for the ncAA L-homoarginine in E. coli [222]. Such an approach has been explored with other sense codons, such as AUG [223], and as a combination of sense and stop codon reassignment [224]. Reassigning single codons is not the only way to incorporate ncAAs to the genetic code. Instead, Hoesl and colleagues [225] have evolved cultures of $E$. coli to grow on a non-canonical amino acid alternative to L-tryptophan (L- $\beta$-(thieno[3,2-b]pyrrolyl)alanine) in a long-term cultivation experiment. While cells were capable of surviving in the total absence of L-tryptophan, they were still able to grow when L-tryptophan was present. In the future, further strain engineering might provide an evolutionary approach to altered strains dependent on ncAAs.

The resulting combination of trophic and semantic containment constitutes a powerful biosafety system. While not preventing the transfer of genetic material in the first place, the recoded DNA cannot be expressed after an HGT event in natural organisms. Moreover, HGT of sequences encoding an aaRS and the corresponding tRNA are either lethal or very detrimental in natural, non-recoded organisms as they will lead to mistranslation of amber containing genes.

In 2006, Wang et al. recoded the amber codon to implement a non-canonical amino acid. The source organism of the altered tRNA and aminoacyl tRNA synthetase for tyrosine was Methanococcus jannaschii [226]. After engineering, this system was able to insert O-methyl-L-tyrosine in a gene encoding the dihydrofolate reductase. Another example, based on a translation switch controlled by the absence of 3-iodo-L-tyrosine [221, 227], is described in the section on auxotrophy-based systems.

Shifty codes [228] are used to encode the same product as expected in the wild type, but are based on quadruplets and orthogonal ribosomes. The evolution of orthogonal ribosomes translating a quadruplet code provides the amazing opportunity to assign 256 blank codons. Neumann et al. [229] evolved a synthetic ribosome (ribo-Q1), whose decoding fidelity was as high as in wild type ribosomes [230]. They tested the incorporation of two non-canonical amino acids, $\mathrm{p}$-azido-L-phenylalanine (AzPhe) and N6-[(2-propinyloxy)carbonyl]-L-lysine) (CAK), encoded by a combination of a quadruplet codon AGGA and the amber codon UAG in E. coli. The protein was only completely synthesized when both noncanonical amino acids were encoded in the DNA $[229,231,232]$. 


\section{Application of xenobiology-based containment in the iGEM competition}

In 2012, team Paris Bettencourt [104] worked on an extensive biosafety project (Table 1). A semantic containment part was based on an amber mutation in the gene conferring kanamycin resistance (BBa_P1003). The objective was to prevent expression of the antibiotic resistance gene in wild type bacteria cells after a HGT event. Two parts were constructed to realize the amber suppression in E. coli MG1655: BBa_K914000 encoding $\mathrm{P}_{\text {lac }}$-supD-T: tRNA amber suppressor and BBa_K914009:

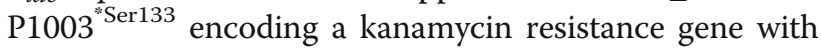
one amber mutation at a serine residue at position 133 .

The team demonstrated that the amber codon was effectively recoded. The growth rate and level of resistance were not significantly decreased compared to the strain carrying the original kanamycin resistance gene as well as the tRNA amber suppressor. However, the culture without the tRNA amber suppressor reached a higher $\mathrm{OD}_{600}$ value, because other amber stop codons on the chromosome were also suppressed. Interestingly, they found that a single amber mutation was quickly overcome by mutations, a problem that could be addressed by introducing a second amber mutation in the kanamycin resistance gene. Thus, amber codons within antibiotic resistances are an effective way to prevent the easy spread of such resistances. However, further improvements of the system are needed to prevent the HGT of the amber suppressing tRNA.

The team TU Darmstadt 2016 [233] combined auxotrophic incorporation of a non-canonical amino acid and a reporter for low levels of the ncAA (BBa_K1416000, BBa_K1976025) [234] designed by the team Austin Texas 2014 [235]. Amber codons were placed at the beginning of a Colicin E2 immunity protein [236] and the mutated Zif23-GCN4 repressor (F4OMT), a dimeric Cis2His2 zinc finger protein [237]. In case of the absence of the ncAA, both proteins cannot be translated, resulting in expression of the reporter system mVenus [238] under control of a Zif23-GCN4-controlled promoter and subsequent initiation of the suicide reaction. However, no results were reported on the expression of the reporter and the OMT-RS expression under a T7 promoter (BBa_K525998).

Team Bielefeld-CeBiTec 2017 worked on expanding the genetic code with the unnatural base pair formed between isoguanosine (isoG) and 5-methyl-isocytosine (iso $\mathrm{C}^{\mathrm{m}}$ ), and non-canonical amino acids [239]. The team used CRISPR/ Cas9 to retain the unnatural base pair in a specified sequence. Furthermore, the algae transporter PtNTT2 was used to facilitate uptake of the unnatural nucleoside triphosphates. Given that this transporter can also facilitate transport of ATP, it may also be used to engineer an artificial ATP auxotrophy. By recoding the amber codon, the team incorporated ncAAs in a number of proteins. Cultivations showed growth defects if the desired ncAA was not supplemented. The cells were still able to grow as the aaRS, with lower affinity, also incorporated endogenous amino acids. Therefore, engineering artificial ncAA auxotrophies requires highly specific aaRS.

\section{Minimal genome}

Sometimes referred to as the "holy grail" of synthetic biology [240-243] the minimal genome is defined as a set of genes which are essential for survival of the cell [244] in an environment containing all required supplements for life [240]. The size of a minimal genome depends on the surrounding environment [245]. Therefore, the sets of required genes differ slightly as reviewed by Gil and colleagues [246]. Most approaches rely on transposon mutagenesis [247] or antisense RNA [248, 249] to identify essential genes [250]. Nevertheless, it is hard to determine the minimal set of essential genes, since an essential function might be encoded by two or more genes, thus resulting in false negative assignments $[245,251]$.

Minimal genomes can be constructed via "top down" or "bottom up" approaches, with "top down" being the systematic deletion of redundant genes, while "bottom up" describes the synthesis and assembly of a genome with the minimal set of genes [252]. Numerous, sophisticated attempts were made to identify essential genes of an organism in order to construct a minimal genome of Haemophilus influenzae [253], H. influenza and Streptococcus pneumoniae [254], Mycoplasma genitalium [255, 256] S. aureus [249], Buchnera spp. [257], Saccharomyces cerevisiae [258], Corynebacterium glutamicum [259] and E. coli [260-262].

In $M$. genitalium, which had the smallest known genome at that time [263], global mutagenesis led to the identification of 265 essential genes [256] which aligns well with the published predicted minimal genome consisting of 256 genes [264]. An 1.08 Mbp synthetic genome sequence of $M$. mycoides was assembled and transplanted into an $M$. capricolum recipient cell producing M. mycoides JCVI-syn1.0 [265]. Latest research has led to the development of a minimal genome of $M$. mycoides called JCVI-syn3.0 [245]. Based on JCVI-syn1.0, the genome reduction was achieved in 2016 in the new synthetic $532 \mathrm{kbp}$ genome of JCVI-syn3.0 [245]. It contains the minimal set of essential genes, although the function of 149 genes remained unknown. Further reduction processes identified quasi essential genes, which were not required for survival, but contributed significantly to stable growth [245]. Cells with a reduced genome showed a duplication time of $180 \mathrm{~min}$, which is substantially different to the duplication time of $60 \mathrm{~min}$ of JCVI-syn 1.0 with a gene set for robust growth [245]. 
A bacterial cell with a minimal genome offers various applications in biosafety. The cells would depend on complex media as well as on stable conditions. Therefore, survival in a natural environment with fluctuations in environmental conditions is improbable. However, HGT is still an issue in this scenario, which is why we recommend aiming for a combination with self-destruction systems as described above.

Since the iGEM competition is about the construction of plasmid-based BioBricks, the development of a minimal genome would be challenging for the teams. Still, teams like Alberta 2009 [266], ETH Zurich 2008 [267], and UESTC 2015 [268] developed concepts and implemented software to identify minimal gene sets based on bacterial genome sequences.

\section{Cell-free systems}

The main concerns from a biosafety perspective are the possible release of GMOs into the environment and HGT between engineered and wild type organisms. Cell-free protein synthesis (CFPS) represents a promising possibility to eliminate most of these risks. The first researchers to show that disrupted bacterial cells can be used for in vitro protein synthesis were Gale and Folkes in 1954 [269]. In 1961, Nirenberg and Matthaei conducted pioneering work using $E$. coli cells and showed that template RNA is a requirement for cell-free protein synthesis [270]. CFPS is feasible for a variety of applications, including synthetic biology, vaccine production and protein engineering [271-273].

There are two main strategies for CFPS. The first, older one is based on crude cell extracts from the desired cells. While the necessary crude extracts are easy to prepare, fast energy depletion and degradation by proteases and nucleases pose two major problems [274-276]. To counter those problems, the PURE ("protein synthesis using recombinant elements") system developed by Shimizu et al. 2001 [276] can be used. This cell-free system is based on purified (His)-tagged translation factors and can be programmed by natural mRNA. For biosafety reasons, it is important to effectively remove all living cells before deploying a CFPS system outside of the lab. While standard methods for the preparation of cell-extracts are already highly effective, they still do not provide a completely cell-free extract $[277,278]$. Protocols based on sterile filtration and lyophilization can provide a much more sterile extract, minimizing the risk of accidental release of genetically modified organisms into the environment [278]. To fully circumvent the risk of an unsterile cell-extract, the aforementioned PURE system can be deployed. This system is not only safer, but also has lower energy consumption relative to S30 cell extract systems (cell extracts cleared from heavier components by centrifugation at 30,000 xg), with greater productivity. However,
Shimizu et al. could not top the productivity of $400 \mu \mathrm{g} / \mathrm{ml}$ with a S30 extract when they first published their results [276, 279].

Several iGEM teams used cell-free systems for their projects. Bielefeld-CeBiTec 2015 (Table 1) used cell extracts of E. coli KRX and ER2566 strains to produce sfGFP as part of a paper-based biosensor [280]. Both strains feature low endogenous protease activity and a chromosomally integrated T7 polymerase. To create a cell extract, the team harvested the cells at mid-to-late exponential growth phase and sonicated the cells as described by Kwon and Jewett [281]. Using this system, the team successfully produced sfGFP in vitro on a paper strip.

Teams Edinburgh 2015 and Exeter 2015 also tried to build a biosensor using cell-free protein synthesis. Edinburgh used $E$. coli BL21 to express the desired enzymes fused to cellulose-binding domains. The cells were freeze-dried to obtain an extract containing the enzymes which were then immobilized on paper to create a paper-based drug testing biosensor [282]. Exeter 2015 developed a biosensor for the detection of bovine tuberculosis. The team used a commercially available S30 cell-free kit to express GreenFET1J as a response to the trigger RNA [283].

Team Freiburg 2015 tried to build a microchip for simultaneous detection of several infectious diseases [284]. The team used an E. coli lysate in a microfluidic chamber and expressed HA- and (His)-tagged GFP as well as luciferase as a proof of concept. Their final goal was to express disease-specific antigens like the Clostridium tetani antigen, however even after optimization, antigen production could not be detected.

In 2017, team Lethbridge worked on a standardized, modular system for CFPS with their project 'next vivo' [285]. The design of the system was based on standardized expression and purification of all proteins required for transcription and translation, the ribosomes, as well as the necessary tRNAs. The team aimed to overexpress all 38 essential proteins required for transcription and translation in E. coli BL21-Gold (DE3) to subsequently pool and co-purify all components. The team successfully overexpressed and purified key proteins required for CFPS and succeeded in purifying tRNA ${ }^{\text {Phe }}$ as a proof of concept. Additionally, the team hypothesized the use of a modified codon table as a biocontainment strategy for CFPS.

\section{Physical containment}

While biological strategies have strengthened biocontainment, most strategies, especially in industry, are centered around physical containment [56]. We define physical containment as the separation of cells from the environment by means of physical materials e.g. the wall 
of a bioreactor [23]. Physical containment acts as a preemptive strategy intended to prevent the release of GMOs and includes the design of equipment as well as facilities used [56]. Besides "classical" full containment systems like bioreactors, cell retainment systems which allow the exchange of small molecules, e.g. micro encapsulation, enable a broad range of applications [286-289]. In theory, cells should secrete their product, e.g. neurotransmitter [290, 291], continuously over a long-time period. However, this mechanism requires expensive viability controls and the development of mechanisms to prevent unintended release of bacteria from capsules [292]. Stability of encapsulation can be increased by chelating compounds, anti-gelling cations like $\mathrm{Na}^{+}$and $\mathrm{Mg}^{2}$ + or polymers [293, 294].

The survival rate of cells in silica gels as encapsulating substance [295-297] reached 55\% living cells after 4 weeks by adding glycerol as osmotic stabilizer [298]. The specific advantage of silica gels is their action as physical barriers between the cells, preventing cell aggregation and thus physical interaction between cells [298]. Although there is a mechanical and chemical stability of silica gels which ensure entrapment of cells, silica gels are still not as stable as polymer gels [299-301].

Since iGEM applications are often targeting environmental problems or offer applications for daily use, the development of solutions for encapsulated cells is a pressing need. Such physical containment strategies were applied by Paris Saclay 2015 to embed bacteria in silica beads [302]. They developed a novel protocol based on two publications [303, 304] which remains to be tested.

Paris Bettencourt 2012 worked on alginate beads for application with $E$. coli, based on a study with $S$. cerevisiae [305], using glutaraldehyde as a cross-linker [104]. This compound is toxic to unprotected cells but can be used together with polyethyleneimine to stabilize the cells within the alginate beads. Blue white staining was applied to demonstrate the viability of encapsulated $E$. coli cells. The stabilized beads showed a 1000-fold reduced cell-release rate. This was demonstrated by cultivating cells entrapped by both types of beads for $24 \mathrm{~h}$ followed by streaking out the supernatant on agar plates to quantify the number of released cells.

\section{Sensors}

In a broader sense, physical containment can be understood also as the containment by physical parameters like temperature or light. These parameters are suitable as they are usually well controlled in a bioreactor. In addition, a number of control systems can be found in many organisms, as living cells must adapt to changes in the temperature and light condition of their environment. By sensing these (or other) environmental conditions, release of bacterial cells from a controlled environment can be linked to other biosafety systems, like kill switches.

\section{Temperature}

Depending on the organism, release from the physical containment might result in either a heat or cold shock which could be used to differentiate between growth in a temperature-controlled environment like a bioreactor or in a natural environment, respectively [306, 307].

As many organisms encounter (sometimes drastic) changes in temperature in nature, a wide variety of sensors and response systems have evolved in bacteria and other organisms. For example, over 100 proteins were previously described to be involved in the heat shock response of $E$. coli [308-310]. Most of these proteins function as molecular chaperons or proteases, which preserve the protein structures, membrane homeostasis or nucleic acid topology [308-310]. On the other hand, cold shock proteins (CSPs) allow to tolerate low temperatures by maintaining efficient translation of RNA and membrane fluidity [311, 312]. Another group of proteins are methyl-accepting chemotaxis proteins (MCPs) which are involved in temperature-dependent changes in the movement of E. coli. Of these Tsr, Tar and Trg were described to detect heat shock temperatures while Tap detected low temperatures [313-316].

A more direct level of temperature-based control is realized on the DNA and RNA levels. For example, transcription efficiency is dependent on the DNA topology, especially on the level of supercoiling [317-319] which can increase or decrease due to temperature stress [320]. Another common control mechanism that has been recognized is on the level of RNA in the form of riboswitches. These elements are usually located within the 5 '-UTR of protein encoding genes [321] and control protein biosynthesis through temperature-mediated structural changes [322-324]. They usually consist of temperature unstable hairpin loops [325], but more sophisticated RNA structures like the pseudo knot structure of the $\operatorname{csp} A$ transcript [326] are also known. The typical mode of action of these 'RNA thermometers' is sequestration of the RBS by hairpin formation which is released at elevated temperatures [327]. Beside cis-acting RNA molecules, at least one trans-acting RNA has been described: DsrA affects the expression of other genes through modulation of translation of rpoS, encoding the non-essential sigma factor of RNA polymerase in E. coli, at low temperatures by binding to the rpoS transcript, releasing the otherwise sequestered RBS [328-330].

Promising work has been done on the integration of riboswitches into biosafety systems regarding gene expression [331, 332]. Dedicated non-coding RNA 
molecules were frequently applied to measure temperatures in vivo [333-335]. Multiple examples of temperature sensing RNA molecules integrated as key part of a biosafety system were presented by iGEM teams during the last years (Table 1) [30, 31]. Team Paris Saclay 2015 applied the RNA-based temperature sensor technology to set upper $\left(42{ }^{\circ} \mathrm{C}\right)$ and lower $\left(32{ }^{\circ} \mathrm{C}\right)$ temperature boundaries for growth of $E$. coli [302]. The RNA molecule ROSE [336] from Bradyrhizobium japonicum [337] was proposed to control the expression of three essential genes in E. coli. Genes encoding the tRNA synthetases for alanine, tyrosine and methionine as well as the DNA polymerase III subunit delta might be good targets for conditional expression [262]. Other potential targets, which are essential, non-redundant and constitutively expressed, include adenylate kinase ( $a d k$ ) [338], alanyl-tRNA synthethase [339], DNA polymerase III subunit delta (holB) [340], methionyl-tRNA synthetase (metG) [341], phosphoglycerate kinase (pgk) [342], and tyrosyl-tRNA synthetase (tyrS) [343].

The native promoter sequences of three essential genes were substituted with a repressor-controlled tet promoter $\left(\mathrm{P}_{t e t}\right)$ [344]. ROSE was applied to control the expression of the TetR repressor to indirectly regulate the expression of all three tRNA synthetases. Since ROSE inhibits translation of the controlled mRNA below $30{ }^{\circ} \mathrm{C}$ [336], E. coli is only able to grow above this temperature when the Tet repressor is translated. The $c I$ gene from bacteriophage $\lambda$ was applied to achieve an upper growth limit, which may be important for applications involving thermotolerant or thermophilic bacteria. While an upper restrictive temperature is not necessary for application in most environments, the concept of producing a stenoecious (insensitive to environmental factors) organism by synthetic biology is very interesting.

Another good example is the use of the RNA molecule FourU from Salmonella entericaserovar Typhimurium M556 [345] (BBa_K115002) by the iGEM teams TU Delft 2008 [346] as well as NCTU Formosa 2011 [347]. Expression of essential genes is controlled by this temperature-sensing RNA molecule, permitting the $E$. coli cells to grow only at $37{ }^{\circ} \mathrm{C}$. Growth at lower temperature is inhibited by the formation of a stable RNA hairpin structure which prevents the translation of essential genes [345]. Growth at higher temperatures is not possible, since the high temperature is detrimental to E. coli. Functionality of this part was demonstrated via Renilla reniformis luficerase [348] and GFP [349] respectively, serving as reporter genes.

\section{Light-regulated gene expression}

Light exposure is a major difference between the controlled environment within a bioreactor and the natural environment. Therefore, light sensors [350, 351] might be applicable in microbial biosafety systems when coupled to kill switches or other previously described systems.

One way for perception of light in bacteria are LOV photoreceptors [352] based on flavine nucleotides as chromophores [353]. A synthetic biology approach replaces the oxygen-sensing module of the histidine kinase FixL [354] of B. japonicum [355] with the LOV photo sensor module of YtvA from B. subtilis [356]. The resulting histidine kinase YF1 can be inhibited by blue light. The combination of the response regulator FixJ of $B$. japonicum [357] and YF1 forms a synthetic two component system. This system controls the FixK2 promoter [355] allowing light-dependent repression of genes under $\mathrm{P}_{\text {fix } K 2}$ control [352], realized on the plasmid pDusk [358, 359]. For biosafety purposes, the opposite behavior is usually desired, requiring the use of an inverter. A ready to use system is available via the plasmid pDawn which uses a Yf1-FixJ-downregulated $c I$ as well as a cI-repressed $\mathrm{P}_{\mathrm{R}}$ upstream of the gene(s) of interest [358, 359]. Despite the availability of BioBricks, only a few iGEM teams have proposed to use this system for biosafety. To our knowledge, no team has so far successfully used the system for this purpose.

Phytochromes are another type of a membrane-bound extracellular sensor for light detection which regulate transcription via intracellular response regulators [360]. A synthetic biology approach involves the fusion of this photoreceptor and an intracellular E. coli histidine kinase domain [361]. This system is based on the EnvZ-OmpR two component system of E. coli which is involved in porin expression upon osmotic shock [362]. The chimera protein was constructed by replacing EnvZ with the phytochrome Cph1 of Synechocystis sp. PCC 6803 [363, 364]. The light-sensing receptor part (phycocyanobilin) is not produced in E. coli wildtype. However, phycocyanobilin biosynthesis can be achieved in E. coli by introducing the genes hol (BBa_I15008) und pcyA (BBa_I15009) of Synechocystis sp. PCC6803 resulting in conversion of haem into phycocyanobilin $[365,366]$. The chimeric protein Cph8 (encoded by BBa_I15010) reacts to light input with a strong response. This systems allows expression of the target gene(s) in the dark to be inactivated by red light [361].

The teams of Uppsala 2011 [367] and Cornell 2011 [368] conceptualized light-dependent biosafety systems. Green light was used by the Cornell team to trigger the expression of a lysis cassette. As green light is absent under normal cultivation conditions, this system should kill all cells outside a bioreactor. Cornell 2011 planned the combination of $c c a S$ and $c c a R$ on one plasmid in combination with the phycocyaobilin biosynthesis genes ho1 and pcyA (BBa_K597105). 


\section{Conclusion}

We reviewed a broad spectrum of biosafety mechanisms and have highlighted promising achievements within the iGEM competition (Table 1). Auxotrophies, kill switches, mechanisms for self-destruction, and semantic as well as physical containment are important categories of orthogonal biosafety systems. Moreover, cell-free approaches provide biosafety to synthetic biology by avoiding living cells.

Despite these sophisticated mechanisms, responsible and careful handling of genetically engineered bacteria is the first step and most efficient way to ensure biosafety. However, in the case of an accidental release of genetically engineered bacteria, several mechanisms should be in place to prevent the spread of the engineered cells or their genetic information. It is important to emphasize that genetic components, process conditions and manufacturing design can all contribute to biocontainment and should therefore be taken into consideration to further increase the degree of biosafety [56]. Most standard safety strains are only based on auxotrophies, designed to prohibit growth in absence of one specific compound. Even if genetically modified cells are not able to survive in the environment, the presence of recombinant genetic information still provides opportunities for HGT. As any single biosafety system might fail with roughly the probability of a point mutation $\left(10^{-7}\right)[369,370]$, a combination of multiple systems can increase the safety in a linear way (Fig. 3). Therefore, it is important to combine orthogonal types of biosafety mechanisms within one cell $[32,76]$, resulting in safer, more sophisticated, synthetic biosafety systems. Such systems can be combined within one cell, as highlighted in (Fig. 4).

Calculating the worse-case probability, we assume only a linear safety increase which would require five different systems to reach a failure probability of $10^{-35}$. Since recent estimations assume the presence of only about $10^{30}$ cells on earth [371], one could consider such a combined system as sufficiently safe for a single application. To achieve a high level of biosafety, several systems preventing HGT as well as VGT should be combined as each system might fail with a certain probability (Fig. 3, Table 2). However, it is important to keep in mind that the number of synthetic biology applications will increase significantly in the near future. Like the correction for multiple testing in statistics, the failure probability of biosafety systems in the future should be adjusted in accordance to the number of parallel applications. Therefore, a general awareness of potential risks associated with this technology is crucial. Whilst the number of early stage researchers utilizing methods of synthetic biology has increased through the iGEM competition, the teams have regularly conceptualized and successfully implemented novel biosafety systems

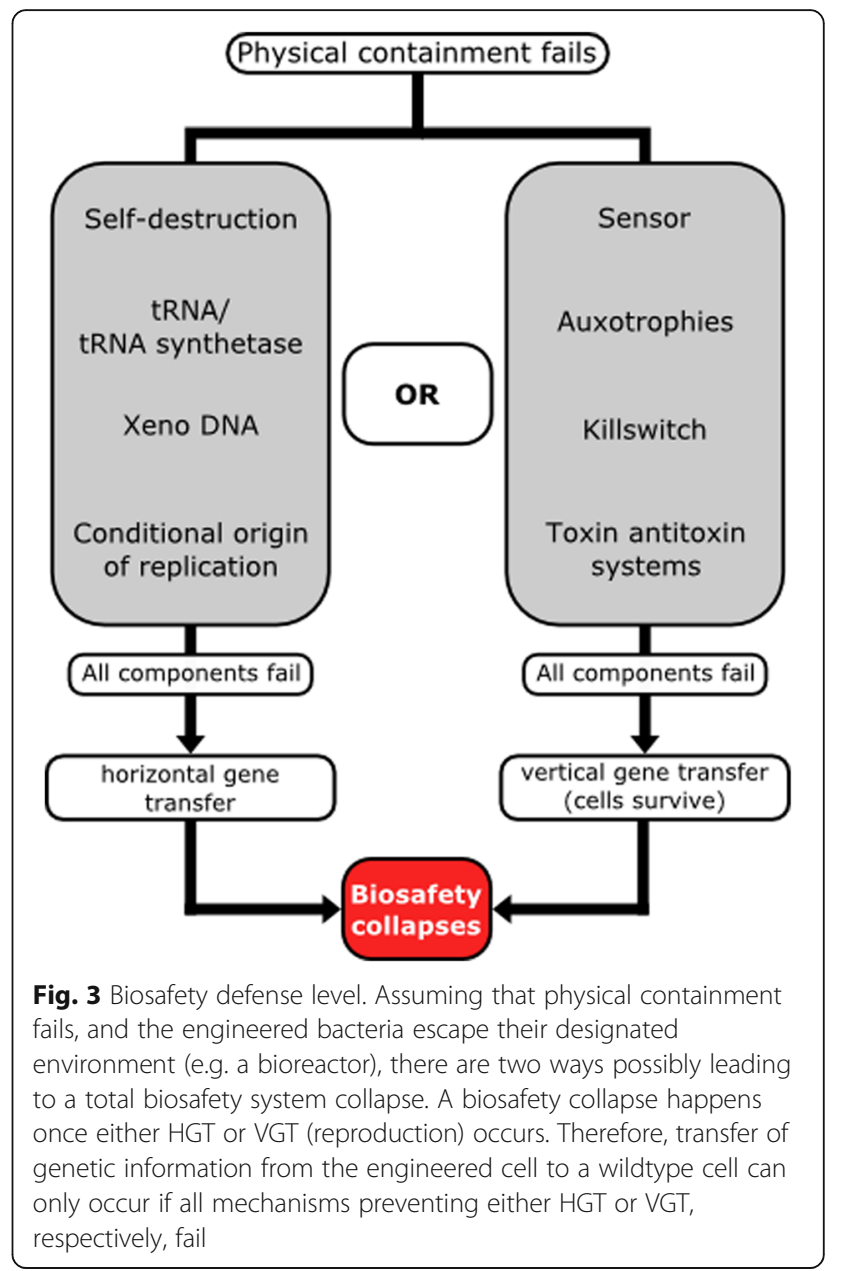

(Table 1). The awareness for this topic seems to be higher than in general research. A dedicated biosafety track could support this development and facilitate the submission of well characterized biosafety BioBricks to the iGEM Registry of Standard Biological Parts. Furthermore, since only the submission of parts (not the submission of engineered strains) to the Registry of Standard Parts is possible, iGEM teams are limited to the construction of plasmid-based biosafety devices. Enabling a controlled strain distribution alongside the BioBrick collection could facilitate the invention of even more sophisticated systems.

So, what comes next? Given that biotechnology is becoming more and more established in industry, complex biosafety systems that can efficiently prevent vertical as well as HGT are of high interest. Furthermore, GMOs designed to be deployed in open environments pose new biosafety challenges. An example for such applications can include the possible use of engineered microbes for bioremediation of chemically polluted areas [372, 373]. Given that the technological advancements over the last decades have led to a much deeper understanding of 


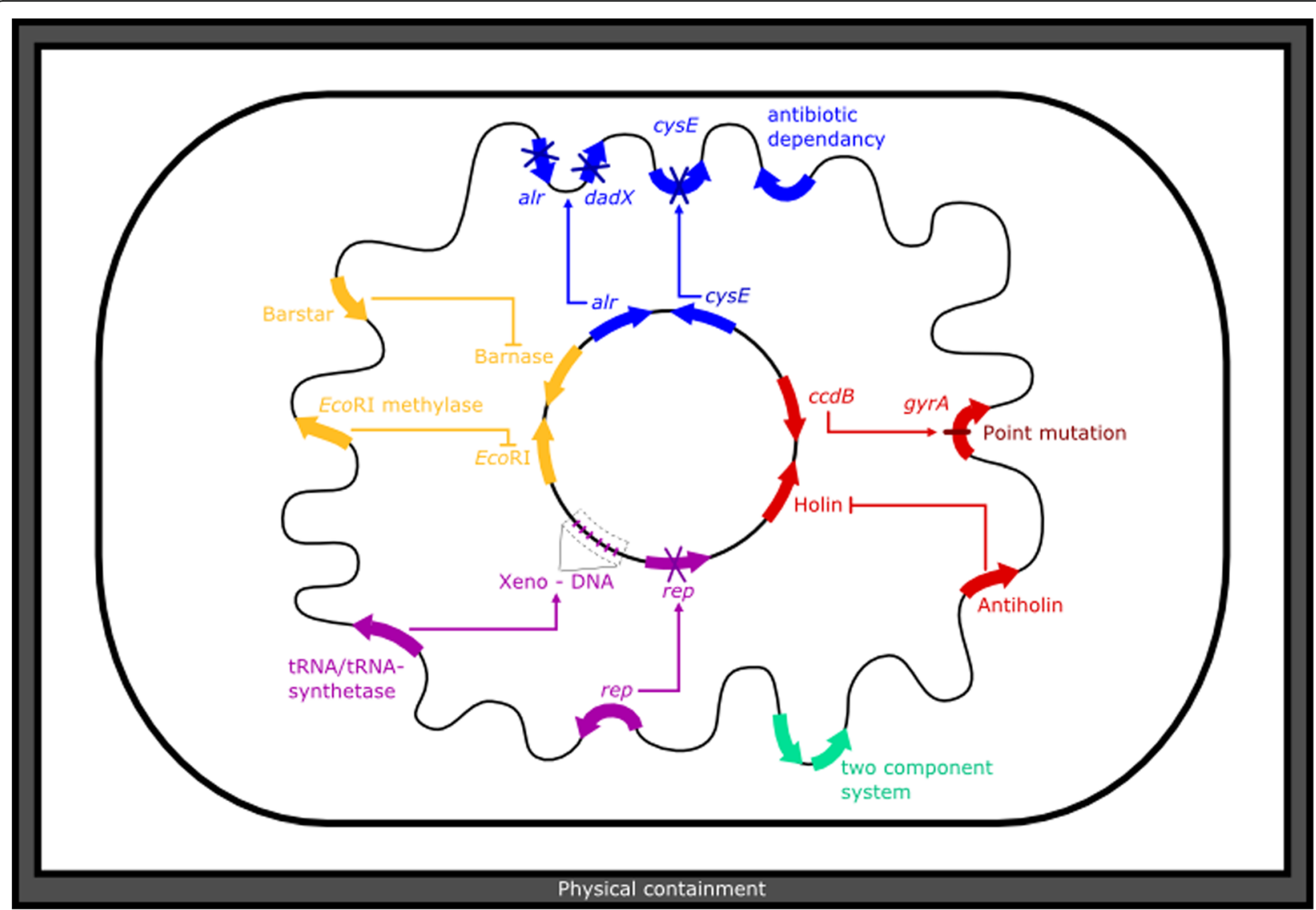

Fig. 4 Comprehensive combination of biosafety mechanisms in E. coli. Proposed combination of orthologous biosafety mechanisms. Auxotrophies (blue), TA-systems (red), replication control mechanisms (purple) and self-destruction systems (yellow) could be combined to achieve a high-quality biosafety system. Furthermore, the proposed combination of systems includes physical containment (grey) and a two-component system (green) to enhance the reliability even further. To create artificial auxotrophies, alr, dadX and cysE were deleted in the genome and must be replaced with plasmid-bound gene copies. CcdB and Holin serve as toxins, but their toxicity will only effect wildtype cells. The toxicity of CcdB can be avoided through a single point mutation within the gyrA gene. To neutralize the toxicity of holin, an antiholin-encoding gene is present in the genome of the desired host. By moving the rep gene from the plasmid to the genome, the plasmid can only replicate if Rep is provided in trans. Incorporation of artificial bases into the plasmid (Xeno-DNA) prevents wildtype cells without the corresponding tRNA/tRNA-synthetase to produce any of the encoded proteins. To destroy the plasmid DNA if taken up by wildtype cells, self-destruction systems like barnase and EcoRl are included. Only the desired host possesses the corresponding inhibitors Barstar and EcoRI methylase and hence can counteract the toxicity

cellular biology and regulatory processes, it is likely that novel and more advanced biosafety approaches will be developed in the near future. Especially cell-free xenobiological systems would be of high interest as potential high-fidelity synthetic biosafety systems. Novel synthetic biosafety systems could even allow for safer deployment of GMOs in open environments.

In the future, we propose the construction of customized safety strains by harnessing the extensive knowledge collected through genome sequencing and functional annotation projects. On the one hand, pathway mapping could be used to find target genes which might circumvent certain auxotrophies. On the other hand, the identification of bottle necks in essential pathways for generating novel auxotrophies is feasible now. Moreover, basic research e.g. about mechanisms of HGT and bacterial evolution is needed to quantify the safety of previously described mechanisms more precisely.

\section{Abbreviations}

aaRS: aminoacyl-tRNA synthetase; aTc: anhydrotetracycline; CeNA: Cyclohexene nucleic acid; CFPS: Cell-free protein synthesis; CMO: Chemically modified organism; CRISPR/Cas: Clustered regularly interspaced short palindromic repeats/CRISPR associated; CSP: Cold shock proteins; DAP: Diaminopimelic acid; GMO: Genetically modified organism; GNA: Glycerol nucleic acid; GRO: Genetically recoded organism; HGT: Horizontal gene transfer; HIV: Human immunodeficiency virus; HNA: Hexitol nucleic acid; iGEM: international Genetically Engineered Machine; MCP: Methyl-accepting chemotaxis protein; ncAA: non-canonical amino acid; NSAA: Non-standard amino acid; NTP: Nucleoside triphosphate; OTS: Orthogonal translation system; PAM: Protospacer-adjacent motive; QAPRTase: Chromosomal quinolinic acid phosphoribosyltransferase; RBS: Ribosome binding site; SAA: synthetic amino acid; sfGFP: super folder GFP; sgRNA: single-guide RNA; SLiDE: Synthetic auxotroph with ligand-dependent essential genes; TA: Toxin-antitoxin; TD: Threonine deaminase; TNA: Threose nucleic acid; xDNA: expanded DNA; XNA: Xeno DNA; yDNA: wide DNA 


\section{Acknowledgements}

We are grateful to the entire iGEM team Bielefeld-CeBiTec 2017. We thank Lara Makewita and Nathanael Walker-Hale for language editing and proof reading. We acknowledge the financial support of the German Research Foundation (DFG) and the Open Access Publication Fund of Bielefeld University for the article processing charge.

\section{Availability of data and materials}

The datasets described in this review are freely available at the Registry of Standard Biological Parts, http://parts.igem.org/Main_Page.

\section{Authors' contributions}

$J \mathrm{D}$ and BP designed research. SD, DK, CM, OS and CMW wrote the initial draft. ME designed figures. CMW, JD, BP, CR and JK revised the manuscript. All authors read and approved the final manuscript.

\section{Authors' information}

SD, DK, CM, OS, ME and CMW participated in IGEM 2017 in the team 'Bielefeld-CeBiTec' focusing on biosafety aspects of the project. JD and BP are fascinated by synthetic biology and especially biosafety since their participation in iGEM 2014. CR and JK are experts in synthetic biology supervising iGEM teams in Bielefeld since 2010.

\section{Ethics approval and consent to participate}

Not applicable.

\section{Consent for publication}

Not applicable.

\section{Competing interests}

The authors declare that they have no competing interests.

\section{Publisher's Note}

Springer Nature remains neutral with regard to jurisdictional claims in published maps and institutional affiliations.

\section{Author details}

${ }^{1}$ Center for Biotechnology, Bielefeld University, 33615 Bielefeld, Germany. ${ }^{2}$ Faculty of Biology, Bielefeld University, Bielefeld, Germany. ${ }^{3}$ Present address: Evolution and Diversity, Department of Plant Sciences, University of Cambridge, Cambridge, UK.

Received: 17 January 2018 Accepted: 25 June 2018 Published online: 14 August 2018

\section{References}

1. Bakanidze L, Imnadze P, Perkins D. Biosafety and biosecurity as essential pillars of international health security and cross-cutting elements of biological nonproliferation. BMC Public Health. 2010;10(Suppl 1):S12. https:// doi.org/10.1186/1471-2458-10-S1-S12.

2. Sewell DL. Laboratory-associated infections and biosafety. Clin Microbiol Rev. 1995:8:389-405.

3. Gaudioso J. Science and government: biosecurity and research: minimizing adverse impacts. Science. 2004;304:687. https://doi.org/10.1126/science. 1096911.

4. Cohen SN. DNA cloning: a personal view after 40 years. Proc Natl Acad Sci. 2013;110:15521-9. https://doi.org/10.1073/pnas.1313397110.

5. Curtiss III R, Alexander J, Alexander L, Clark-Curtiss O, Goldschmidt R, Hsu C, et al. Biological Containment and Cloning Vector-Transmissibility. J Infect Dis. 1978;137:668-75. http://www.ncbi.nlm.nih.gov/pubmed/351084.

6. Miller S, Selgelid MJ. Ethical and philosophical consideration of the dual-use dilemma in the biological sciences. Dordrecht: Springer Netherlands; 2008. https://doi.org/10.1007/978-1-4020-8312-9.

7. Cenciarelli O, Gabbarini V, Pietropaoli S, Malizia A, Tamburrini A, Ludovici GM, et al. Viral bioterrorism: Learning the lesson of Ebola virus in West Africa 2013-2015. Virus Res. 2015;210:318-26. https://doi.org/10.1016/j. virusres.2015.09.002.

8. van Aken J, Hammond E. Genetic engineering and biological weapons. New technologies, desires and threats from biological research. EMBO Rep. 2003;4:Spec No:S57-S60. https://doi.org/10.1038/sj.embor.embor860.
9. $\quad$ Singer M, Soll D. Guidelines for DNA hybrid molecules. Science. 1973;181: 1114. https://doi.org/10.1126/science.181.4105.1114.

10. Berg P, Baltimore D, Nathans D, Boyer HW, Roblin R, Cohen SN, et al. Potential biohazards of recombinant DNA molecules. Science. 1974;185:303.

11. Molin S, Klemm P, Poulsen LK, Biehl H, Gerdes K, Andersson P. Conditional suicide system for containment of Bacteria and plasmids. Nat Biotechnol. 1987:5:1315-8. https://doi.org/10.1038/nbt1287-1315.

12. Blattner FR, Plunkett G, Bloch CA, Perna NT, Burland V, Riley M, et al. The complete genome sequence of Escherichia coli K-12. Science. 1997;277: 1453-62. https://doi.org/10.1126/science.277.5331.1453.

13. Guyer MS, Reed RR, Steitz JA, Low KB. Identification of a sex-factor-affinity site in E. Coli as $\gamma \delta$. Cold Spring Harb Symp Quant Biol. 1981;45:135-40. https://doi.org/10.1101/SQB.1981.045.01.022.

14. Daegelen P, Studier FW, Lenski RE, Cure S, Kim JF. Tracing ancestors and relatives of Escherichia coli B, and the derivation of B strains REL606 and BL21(DE3). J Mol Biol. 2009:394:634-43. https://doi.org/10.1016/j.jmb.2009.09.022.

15. Hanahan D. Studies on transformation of Escherichia coli with plasmids. J Mol Biol. 1983;166:557-80. https://doi.org/10.1016/S0022-2836(83)80284-8.

16. Smith DB, Johnson KS. Single-step purification of polypeptides expressed in Escherichia coli as fusions with glutathione S-transferase. Gene. 1988;67:31-40. https://doi.org/10.1016/0378-1119(88)90005-4.

17. William Studier F, Rosenberg AH, Dunn JJ, Dubendorff JW. Use of T7 RNA polymerase to direct expression of cloned genes. Methods Enzymol. 1990; 185(C):60-89. https://doi.org/10.1016/0076-6879(90)85008-C.

18. Tenover FC, Arbeit RD, Goering RV, Mickelsen PA, Murray BE, Persing DH, et al. Interpreting chromosomal DNA restriction patterns produced by pulsedfield gel electrophoresis: criteria for bacterial strain typing. J Clin Microbiol. 1995:33:2233-9.

19. Datsenko KA, Wanner BL. One-step inactivation of chromosomal genes in Escherichia coli K-12 using PCR products. Proc Natl Acad Sci U S A. 2000;97: 6640-5. https://doi.org/10.1073/pnas.120163297.

20. Anderson ES. Viability of and transfer of a plasmid from, E. coli K12 in the human intestine. Nature. 1975;255:502-4. https://doi.org/10.1038/255502a0.

21. Schweder T, Hofmann $\mathrm{K}$, Hecker BM. Escherichia coli $\mathrm{K} 12$ relA strains as safe hosts for expression of recombinant DNA. Appl Microbiol Biotechnol. 1995;42:718-23.

22. Schweder T, Schmidt I, Herrmann H, Neubauer P, Hecker M, Hofmann K. An expression vector system providing plasmid stability and conditional suicide of plasmid-containing cells. Appl Microbiol Biotechnol. 1992;38:91-3. http:// www.ncbi.nlm.nih.gov/pubmed/1369014.

23. Kimman TG, Smit E, Klein MR. Evidence-based biosafety: a review of the principles and effectiveness of microbiological containment measures. Clin Microbiol Rev. 2008;21:403-25. https://doi.org/10.1128/CMR.00014-08.

24. Andrup L, Nielsen BH, Kølvraa S. Biosafety considerations in industries with production methods based on the use of recombinant deoxyribonucleic acid. Scand J Work Environ Health. 1990;16:85-95. http://www.ncbi.nIm.nih. gov/pubmed/2191426

25. Walton S. Biosafety committees advise less but better DNA research oversight. Bioscience. 1981;31:14-5. https://doi.org/10.1093/bioscience/31.1.14.

26. Dröge M, Pühler A, Selbitschka W. Horizontal gene transfer as a biosafety issue: a natural phenomenon of public concern. J Biotechnol. 1998;64:75-90. https://doi.org/10.1016/S0168-1656(98)00105-9.

27. Snow AA, Andow DA, Gepts P, Hallerman EM, Power A, Tiedje JM, et al. Genetically engineered organisms and the environment: current status and recommendations. Ecol Appl. 2005;15:377-404. https://doi.org/10. 1890/04-0539.

28. Chan CTY, Lee JW, Cameron DE, Bashor CJ, Collins JJ. "Deadman" and "passcode" microbial kill switches for bacterial containment. Nat Chem Biol. 2015;12:82-6. https://doi.org/10.1038/nchembio.1979.

29. iGEM. http://igem.org/Main_Page. Accessed 25 Jun 2017.

30. Guan Z, Schmidt M, Pei L, Wei W, Ma K. Biosafety Considerations of Synthetic Biology in the International Genetically Engineered Machine (iGEM) Competition. Bioscience. 2013;63:25-34. https://doi.org/10.1525/ bio.2013.63.1.7.

31. Vilanova C, Porcar M. iGEM 2.0-Refoundations for engineering biology. Nat Biotechnol. 2014;32:420-4. https://doi.org/10.1038/nbt.2899.

32. Wright O, Delmans M, Stan GB, Ellis T. GeneGuard: a modular plasmid system designed for biosafety. ACS Synth Biol. 2015;4:307-16.

33. Goodman C. Engineering ingenuity at iGEM. Nat Chem Biol. 2008:4:13. https://doi.org/10.1038/nchembio0108-13.

34. Smolke CD. Building outside of the box: iGEM and the BioBricks foundation. Nat Biotechnol. 2009;27:1099-102. https://doi.org/10.1038/nbt1209-1099. 
35. Cooling MT, Rouilly V, Misirli G, Lawson J, Yu T, Hallinan J, et al. Standard virtual biological parts: a repository of modular modeling components for synthetic biology. Bioinformatics. 2010;26:925-31.

36. Cai Y, Wilson ML, Peccoud J. GenoCAD for iGEM: a grammatical approach to the design of standard-compliant constructs. Nucleic Acids Res. 2010;38 2637-44. https://doi.org/10.1093/nar/gkq086.

37. Chen YY, Galloway KE, Smolke CD. Synthetic biology: advancing biological frontiers by building synthetic systems. Genome Biol. 2012;13:240.

38. Harger M, Zheng L, Moon A, Ager C, An JH, Choe C, et al. Expanding the product profile of a microbial alkane biosynthetic pathway. ACS Synth Biol. 2013;2:59-62.

39. Radeck J, Kraft K, Bartels J, Cikovic T, Dürr F, Emenegger J, et al. The Bacillus BioBrick box: generation and evaluation of essential genetic building blocks for standardized work with Bacillus subtilis. J Biol Eng. 2013;7:29. https://doi. org/10.1186/1754-1611-7-29.

40. Chen R, Rishi HS, Potapov V, Yamada MR, Yeh VJ, Chow T, et al. A barcoding strategy enabling higher-throughput library screening by microscopy. ACS Synth Biol. 2015;4:1205-16. https://doi.org/10.1021/acssynbio.5b00060.

41. Kelwick R, Bowater L, Yeoman KH, Bowater RP. Promoting microbiology education through the iGEM synthetic biology competition. FEMS Microbiol Lett. 2015:362:fnv129. https://doi.org/10.1093/femsle/fnv129.

42. Storch M, Casini A, Mackrow B, Fleming T, Trewhitt H, Ellis T, et al. BASIC: a new biopart assembly standard for idempotent cloning provides accurate, single-tier DNA assembly for synthetic biology. ACS Synth Biol. 2015:4:781-7. https:/doi.org/10.1021/sb500356d.

43. Jack BR, Leonard SP, Mishler DM, Renda BA, Leon D, Suárez GA, et al. Predicting the genetic stability of engineered DNA sequences with the EFM calculator. ACS Synth Biol. 2014:4:939-43.

44. Hayashi K, Morooka N, Yamamoto Y, Fujita K, Isono K, Choi S, et al. Highly accurate genome sequences of Escherichia coli K-12 strains MG1655 and W3110. Mol Syst Biol. 2006;2 https://doi.org/10.1038/msb4100049.

45. Gogarten JP, Townsend JP. Horizontal gene transfer, genome innovation and evolution. Nat Rev Microbiol. 2005;3:679-87.

46. Kubyshkin V, Acevedo-Rocha CG, Budisa N. On universal coding events in protein biogenesis. Biosystems. 2018;164:16-25. https://doi.org/10.1016/j. biosystems.2017.10.004

47. Knight RD, Freeland SJ, Landweber LF. Rewiring the keyboard: Evolvability of the genetic code. Nat Rev Genet. 2001;2:49-58.

48. Yokobori SI, Suzuki T, Watanabe K. Genetic code variations in mitochondria: tRNA as a major determinant of genetic code plasticity. J Mol Evol. 2001;53:314-26.

49. Santos MAS, Moura G, Massey SE, Tuite MF. Driving change: the evolution of alternative genetic codes. Trends Genet. 2004;20:95-102.

50. Kubyshkin V, Budisa N. Synthetic alienation of microbial organisms by using genetic code engineering: why and how? Biotechnol J. 2017;12:1600097. https://doi.org/10.1002/biot.201600097.

51. Simon AJ, Ellington AD. Recent advances in synthetic biosafety. F1000Res. 2016:5:2118. https://doi.org/10.12688/f1000research.8365.1.

52. Curtiss IIIR, Inoue M, Pereira D, Hsu JC, Alexander L, Rock L. Construction and use of safer bacterial host strains for recombinant DNA research. In: Scott WA, Werner R, editors. Molecular cloning of recombinant DNA. Academic press; 1977. p. 99-114.

53. Moe-Behrens GHG, Davis R, Haynes KA. Preparing synthetic biology for the world. Front Microbiol. 2013:4:1-10.

54. Beadle GW, Tatum EL. Genetic control of biochemical reactions in Neurospora. Proc Natl Acad Sci. 1941:27:499-506. https://doi.org/10.1073/pnas.27.11.499.

55. E. coli Genetic Resources at Yale CGSC, The Coli Genetic Stock Center, List of Commonly Requested Auxotrophic Strains. https://cgsc2.biology.yale.edu/ Auxotrophs.php. Accessed 25 Jun 2017.

56. Torres L, Krüger A, Csibra E, Gianni E, Pinheiro VB. Synthetic biology approaches to biological containment: pre-emptively tackling potential risks. Essays Biochem. 2016;60:393-410. https://doi.org/10.1042/EBC20160013.

57. Mandell DJ, Lajoie MJ, Mee MT, Takeuchi R, Kuznetsov G, Norville JE, et al. Biocontainment of genetically modified organisms by synthetic protein design. Nature. 2015:518:55-60. https://doi.org/10.1038/nature14121.

58. Rovner AJ, Haimovich AD, Katz SR, Li Z, Grome MW, Gassaway BM, et al. Recoded organisms engineered to depend on synthetic amino acids. Nature. 2015;518:89-93. https://doi.org/10.1038/nature14095.

59. Vidal L, Pinsach J, Striedner G, Caminal G, Ferrer P. Development of an antibiotic-free plasmid selection system based on glycine auxotrophy for recombinant protein overproduction in Escherichia coli. J Biotechnol. 2008; 134:127-36. https://doi.org/10.1016/j.jbiotec.2008.01.011.
60. Rajasekaran P, Seleem MN, Contreras A, Purwantini E, Schurig GG, Sriranganathan N, et al. Brucella abortus strain RB51 leucine auxotroph as an environmentally safe vaccine for plasmid maintenance and antigen overexpression. Appl Environ Microbiol. 2008;74:7051-5. https://doi.org/10. 1128/AEM.01511-08.

61. Dong $W-R$, Xiang L-X, Shao J-Z. Novel antibiotic-free plasmid selection system based on complementation of host Auxotrophy in the NAD De Novo synthesis pathway. Appl Environ Microbiol. 2010;76:2295-303. https:// doi.org/10.1128/AEM.02462-09.

62. Fiedler M, Skerra A. proBA complementation of an auxotrophic E. coli strain improves plasmid stability and expression yield during fermenter production of a recombinant antibody fragment. Gene. 2001;274:111-8. https://doi.org/10.1016/S0378-1119(01)00629-1.

63. Nguyen LV, Cox KM, Ke JS, Peele CG, Dickey LF. Genetic engineering of a Lemna isoleucine auxotroph. Transgenic Res. 2012;21:1071-83. https://doi. org/10.1007/s11248-012-9594-2.

64. Cava F, Lam H, de Pedro MA, Waldor MK. Emerging knowledge of regulatory roles of d-amino acids in bacteria. Cell Mol Life Sci. 2011;68:817-31. https://doi. org/10.1007/s00018-010-0571-8.

65. Tauch A, Götker S, Pühler A, Kalinowski J, Thierbach G. The alanine racemase gene alr is an alternative to antibiotic resistance genes in cloning systems for industrial Corynebacterium glutamicum strains. J Biotechnol. 2002;99:79-91. https://doi.org/10.1016/S0168-1656(02)00159-1.

66. Walsh CT. Enzymes in the D-alanine branch of bacterial cell wall peptidoglycan assembly. J Biol Chem. 1989;264:2393-6. http://www.ncbi.nlm.nih.gov/ pubmed/2644260

67. Chacon O, Feng Z, Harris NB, Cáceres NE, Adams LG, Barletta RG. Mycobacterium smegmatis D-alanine racemase mutants are not dependent on D-alanine for growth. Antimicrob Agents Chemother. 2002;46:47-54. https://doi.org/10.1128/AAC.46.2.47-54.2002.

68. Milligan DL, Tran SL, Strych U, Cook GM, Krause KL. The alanine racemase of Mycobacterium smegmatis is essential for growth in the absence of D-alanine. J Bacteriol. 2007;189:8381-6. https://doi.org/10. 1128/JB.01201-07.

69. Jawale CV, Lee JH. Development of a biosafety enhanced and immunogenic Salmonella Enteritidis ghost using an antibiotic resistance gene free plasmid carrying a bacteriophage lysis system. PLoS One. 2013;8:1-11.

70. Hirota R, Abe K, Katsuura Z, Noguchi R, Moribe S, Motomura K, et al. A novel biocontainment strategy makes bacterial growth and survival dependent on Phosphite. Sci Rep. 2017:7:44748. https://doi.org/10.1038/srep44748.

71. Steidler L, Neirynck S, Huyghebaert N, Snoeck V, Vermeire A, Goddeeris B, et al. Biological containment of genetically modified Lactococcus lactis for intestinal delivery of human interleukin 10. Nat Biotechnol. 2003;21:785-9. https://doi.org/10.1038/nbt840.

72. Braat H, Rottiers P, Hommes DW, Huyghebaert N, Remaut E, Remon J, et al. A phase I trial with transgenic Bacteria expressing Interleukin-10 in Crohn's disease. Clin Gastroenterol Hepatol. 2006;4:754-9. https://doi.org/10.1016/j. cgh.2006.03.028.

73. Lopez G, Anderson JC. Synthetic Auxotrophs with ligand-dependent essential genes for a BL21(DE3) biosafety strain. ACS Synth Biol. 2015;4: 1279-86. https://doi.org/10.1021/acssynbio.5b00085.

74. Deckert K, Budiardjo SJ, Brunner LC, Lovell S, Karanicolas J. Designing allosteric control into enzymes by chemical rescue of structure. J Am Chem Soc. 2012;134:10055-60.

75. Wright O, Stan G-B, Ellis T. Building-in biosafety for synthetic biology. Microbiology. 2013;159(Pt_7):1221-35. https://doi.org/10.1099/mic.0.066308-0.

76. Gallagher RR, Patel JR, Interiano AL, Rovner AJ, Isaacs FJ. Multilayered genetic safeguards limit growth of microorganisms to defined environments. Nucleic Acids Res. 2015;43:1945-54. https://doi.org/10.1093/ nar/gku1378.

77. Bielefeld Germany 2013. http://2013.igem.org/Team:Bielefeld-Germany. Accessed 6 May 2017

78. Bielefeld-CeBiTec 2014. http://2014.igem.org/Team:Bielefeld-CeBiTec. Accessed 22 Mar 2017

79. BYU Provo 2014. http://2014.igem.org/Team:BYU_Provo. Accessed 22 Mar 2017

80. Amsterdam 2015. http://2015.igem.org/Team:Amsterdam. Accessed 22 Mar 2017

81. Unterholzner SJ, Poppenberger B, Rozhon W. Toxin-antitoxin systems: Biology, identification, and application. Mob Genet Elements. 2013;3:e26219. https://doi.org/10.4161/mge.26219. 
82. Hayes F, Van Melderen L. Toxins-antitoxins: diversity, evolution and function. Crit Rev Biochem Mol Biol. 2011;46:386-408. https://doi.org/10.3109/ 10409238.2011.600437.

83. Gerdes K, Gultyaev AP, Franch T, Pedersen K, Mikkelsen ND. Antisense RNA-regulated programmed cell death. Annu Rev Genet. 1997;31:1-31. https://doi.org/10.1146/annurev.genet.31.1.1.

84. Gerdes K, Wagner EGH. RNA antitoxins. Curr Opin Microbiol. 2007;10:117-24.

85. Van Melderen L, Saavedra De Bast M. Bacterial Toxin-Antitoxin Systems: More Than Selfish Entities? PLoS Genet. 2009;5:e1000437. https://doi.org/10. 1371/journal.pgen.1000437.

86. Gerdes K, Rasmussen PB, Molin S. Unique type of plasmid maintenance function: postsegregational killing of plasmid-free cells. Proc Natl Acad Sci U S A. 1986:83:3116-20.

87. Ohnishi Y, Akimoto S, I-Like R. Plasmids promote degradation of stable ribonucleic acid in Escherichia coli. J Bacteriol. 1980;144:833-5.

88. Akimoto S, Ohnishi Y. R483 and F plasmid genes promoting RNA degradation: comparative restriction mapping. Microbiol Immunol. 1982;26:779-93.

89. Kawano M, Aravind L, Storz G. An antisense RNA controls synthesis of an SOSinduced toxin evolved from an antitoxin. Mol Microbiol. 2007:64:738-54.

90. NTU Taida 2012. http://2012.igem.org/Team:NTU-Taida. Accessed 16 Mar 2017.

91. University of Maryland 2015. http://2015.igem.org/Team:UMaryland. Accessed 16 Mar 2017.

92. Roberts RC, Burioni R, Helinksi DR. Genetic characterization of the stabilizing functions of a region of broad-host-range plasmid RK2. J Bacteriol. 1990;172: 6204-16.

93. Bravo A, de Torrontegui G, Díaz R. Identification of components of a new stability system of plasmid R1, ParD, that is close to the origin of replication of this plasmid. Mol Gen Genet MGG. 1987;210:101-10. https://doi.org/10. 1007/BF00337764.

94. Ogura T, Hiraga S. Mini-F plasmid genes that couple host cell division to plasmid proliferation. Proc Natl Acad Sci. 1983;80:4784-8. https://doi.org/10. 1073/pnas.80.15.4784.

95. Lehnherr H, Maguin E, Jafri S, Yarmolinsky MB. Plasmid addiction genes of bacteriophage P1: doc, which causes cell death on curing of prophage, and phd, which prevents host death when prophage is retained. J Mol Biol. 1993;233:414-28. https://doi.org/10.1006/jmbi.1993.1521.

96. Aizenman E, Engelberg-Kulka H, Glaser G. An Escherichia coli chromosomal "addiction module" regulated by 3',5'-bispyrophosphate: a model for programmed bacterial cell death. Proc Natl Acad Sci. 1996;93:6059-63. https://doi.org/10.1073/pnas.93.12.6059.

97. Grady R, Hayes F. Axe-Txe, a broad-spectrum proteic toxin-antitoxin system specified by a multidrug-resistant, clinical isolate of Enterococcus faecium. Mol Microbiol. 2003;47:1419-32.

98. Zhang J, Zhang $Y$, Inouye M. Characterization of the interactions within the mazEF addiction module of Escherichia coli. J Biol Chem. 2003;278:32300-6.

99. Oberer M, Zangger K, Prytulla S, Keller W. The anti-toxin ParD of plasmid RK2 consists of two structurally distinct moieties and belongs to the ribbonhelix-helix family of DNA-binding proteins. Biochem J. 2002;361(Pt 1):41-7. https://doi.org/10.1042/0264-6021:3610041.

100. Marianovsky I, Aizenman E, Engelberg-Kulka H, Glaser G. The regulation of the Escherichia coli mazEF promoter involves an unusual alternating palindrome. J Biol Chem. 2001;276:5975-84.

101. Magnuson R, Lehnherr H, Mukhopadhyay G, Yarmolinsky MB. Autoregulation of the plasmid addiction operon of bacteriophage P1. J Biol Chem. 1996;271:18705-10.

102. Christensen SK, Maenhaut-Michel G, Mine N, Gottesman S, Gerdes K, Van Melderen L. Overproduction of the Lon protease triggers inhibition of translation in Escherichia coli: involvement of the yefM-yoeB toxin-antitoxin system. Mo Microbiol. 2004;51:1705-17. https://doi.org/10.1046/j.1365-2958.2003.03941.x.

103. Amitai S, Yassin Y, Engelberg-Kulka H. MazF-mediated cell death in Escherichia coli: a point of no return. J Bacteriol. 2004;186:8295-300. https:// doi.org/10.1128/JB.186.24.8295-8300.2004.

104. Paris Bettencourt 2012. http://2012.igem.org/Team:Paris_Bettencourt. Accessed 16 Mar 2017.

105. Wageningen UR 2014. http://2014.igem.org/Team:Wageningen_UR. Accessed 16 Mar 2017.

106. UC Berkeley 2008. http://2008.igem.org/Team:UC_Berkeley. Accessed 16 Mar 2017

107. Stirling F, Bitzan L, O'Keefe S, Redfield E, Oliver JWK, Way J, et al. Rational Design of Evolutionarily Stable Microbial Kill Switches. Mol Cell. 2017;68: 686-697.e3. https://doi.org/10.1016/j.molcel.2017.10.033.
108. Fineran PC, Blower TR, Foulds IJ, Humphreys DP, Lilley KS, Salmond GPC The phage abortive infection system, ToxIN, functions as a protein-RNA toxin-antitoxin pair. Proc Natl Acad Sci U S A. 2009;106:894-9. https://doi. org/10.1073/pnas.0808832106.

109. Samson JE, Spinelli S, Cambillau C, Moineau S. Structure and activity of AbiQ, a lactococcal endoribonuclease belonging to the type III toxinantitoxin system. Mol Microbiol. 2013;87:756-68.

110. Blower TR, Fineran PC, Johnson MJ, Toth IK, Humphreys DP, Salmond GPC. Mutagenesis and functional characterization of the RNA and protein components of the toxIN abortive infection and toxin-antitoxin locus of Erwinia. J Bacteriol. 2009;191:6029-39.

111. Masuda H, Tan Q, Awano N, Wu KP, Inouye M. YeeU enhances the bundling of cytoskeletal polymers of MreB and FtsZ, antagonizing the CbtA (YeeV) toxicity in Escherichia coli. Mol Microbiol. 2012;84:979-89.

112. Wang $X$, Lord DM, Cheng H-Y, Osbourne DO, Hong SH, Sanchez-Torres V, et al. A new type $V$ toxin-antitoxin system where mRNA for toxin GhoT is cleaved by antitoxin GhoS. Nat Chem Biol. 2012;8:855-61. https://doi.org/10. 1038/nchembio.1062.

113. LMU Munich 2012. http://2012.igem.org/Team:LMU-Munich. Accessed 17 Mar 2017

114. TU Eindhoven 2014. http://2014.igem.org/Team:TU_Eindhoven. Accessed 17 Mar 2017

115. Inouye H, Barnes W, Beckwith J. Signal sequence of alkaline phosphatase of Escherichia coli. J Bacteriol. 1982;149:434-9. http://www.ncbi.nlm.nih.gov/ pubmed/7035431.

116. Hartley RW. Barnase and barstar. Expression of its cloned inhibitor permits expression of a cloned ribonuclease. J Mol Biol. 1988;202:913-5. https://doi. org/10.1016/0022-2836(88)90568-2

117. Chaudhary VK, Xu YH, FitzGerald D, Adhya S, Pastan I. Role of domain II of Pseudomonas exotoxin in the secretion of proteins into the periplasm and medium by Escherichia coli. Proc Natl Acad Sci U S A. 1988;85:2939-43. http://www.pubmedcentral.nih.gov/articlerender.fcgi?artid=280118\&tool= pmcentrez\&rendertype $=$ abstract

118. Nesmeyanova MA, Tsfasman IM, Karamyshev AL, Suzina NE. Secretion of the overproduced periplasmic PhoA protein into the medium and accumulation of its precursor in phoA-transformed Escherichia coli strains: involvement of outer membrane vesicles. World J Microbiol Biotechnol. 1991;7:394-406. https://doi.org/10.1007/BF00329408.

119. Ramos HJO, Souza EM, Soares-Ramos JRL, Pedrosa FO. A new system to control the barnase expression by a NifA-dependent promoter. J Biotechnol. 2005;118:9-16. https://doi.org/10.1016/j.jbiotec.2005.03.002.

120. Ramos HJO, Souza EM, Soares-Ramos JRL, Pedrosa FO. Antibiosis by Bacillus amyloliquefaciens ribonuclease barnase expressed in Escherichia coli against symbiotic and endophytic nitrogen-fixing bacteria. J Biotechnol. 2006;126: 291-4. https://doi.org/10.1016/j.jbiotec.2006.04.020.

121. Coray DS, Kurenbach B, Heinemann JA. Exploring the parameters of postsegregational killing using heterologous expression of secreted toxin barnase and antitoxin barstar in an Escherichia coli case study. Microbiology. 2017;163:122-30. https://doi.org/10.1099/mic.0.000395.

122. Guzman LM, Belin D, Carson MJ, Beckwith J. Tight regulation, modulation, and high-level expression by vectors containing the arabinose PBAD promoter. J Bacteriol. 1995;177:4121-30.

123. Siegele DA, Hu JC. Gene expression from plasmids containing the araBAD promoter at subsaturating inducer concentrations represents mixed populations. Proc Natl Acad Sci. 1997;94:8168-72. https://doi.org/10.1073/ pnas.94.15.8168

124. UC Berkeley 2007. http://2007.igem.org/Berkeley_UC. Accessed 23 Jun 2017.

125. Valencia UPV 2014. http://2014.igem.org/Team:Valencia_UPV. Accessed 23 Jun 2017.

126. Velkov W. Stress-induced evolution and the biosafety of genetically modified microorganisms released into the environment. J Biosci. 2001;26: 667-83. https://doi.org/10.1007/BF02704764.

127. Thomas CM, Nielsen KM. Mechanisms of, and barriers to, horizontal gene transfer between Bacteria. Nat Rev Microbiol. 2005;3:711-21. https://doi.org/ 10.1038/nrmicro1234.

128. Greenes PJ, Gupta M, Boyer W, Francisco S, Francisco S, Brown WE, et al. Sequence analysis of the DNA encoding the DNA encoding the eco RI endonuclease and Methylase*. Biol Chem. 1980;25:2143-53.

129. Williams RJ. Restriction endonucleases: classification, properties, and applications. Mol Biotechnol. 2003;23:225-43. https://doi.org/10.1385/ MB:23:3:225. 
130. Roberts RJ, Belfort M, Bestor T, Bhagwat AS, Bickle TA, Bitinaite J, et al. A nomenclature for restriction enzymes, DNA methyltransferases, homing endonucleases and their genes. Nucleic Acids Res. 2003;31:1805-12. https:// doi.org/10.1093/nar/gkg274.

131. Roberts RJ. How restriction enzymes became the workhorses of molecular biology. Proc Natl Acad Sci U S A. 2005;102:5905-8. https://doi.org/10.1073/ pnas.0500923102.

132. Roberts RJ, Vincze T, Posfai J, Macelis D. REBASE - enzymes and genes for DNA restriction and modification. Nucleic Acids Res. 2007;35(Suppl. 1):2006-7.

133. University College London 2012. http://2012.igem.org/Team:University_ College_London. Accessed 23 Jun 2017.

134. Molin S, Boe L, Jensen LB, Kristensen CS, Givskov M, Ramos JL, et al. Suicidal genetic elements and their use in biological containment of Bacteria. Annu Rev Microbiol. 1993;47:139-66. https://doi.org/10.1146/annurev.mi.47.100193. 001035

135. Ahrenholtz I, Lorenz MG, Wackernagel W. A conditional suicide system in Escherichia coli based on the intracellular degradation of DNA. Appl Environ Microbiol. 1994;60:3746-51. http://www.ncbi.nlm.nih.gov/pubmed/7986048

136. Ball TK, Saurugger PN, Benedik MJ. The extracellular nuclease gene of Serratia marcescens and its secretion from Escherichia coli. Gene. 1987;57: 183-92. https://doi.org/10.1016/0378-1119(87)90121-1.

137. Biedermann K, Jepsen PK, Riise E, Svendsen I. Purification and characterization of a Serratia marcescens nuclease produced by Escherichia coli. Carlsb Res Commun. 1989;54:17-27. http://www.ncbi.nlm.nih.gov/ pubmed/2665765

138. TU Munich 2013. http://2013.igem.org/Team:TU-Munich. Accessed 23 Jun 2017.

139. NTU LIHPAO Taiwan 2015. http://2015.igem.org/Team:NTU-LIHPAO-Taiwan. Accessed 23 Jun 2017.

140. Bhaya D, Davison M, Barrangou R. CRISPR-Cas Systems in Bacteria and Archaea: versatile small RNAs for adaptive defense and regulation. Annu Rev Genet. 2011:45:273-97. https://doi.org/10.1146/annurev-genet-110410-132430.

141. Terns MP, Terns RM. CRISPR-based adaptive immune systems. Curr Opin Microbiol. 2011;14:321-7.

142. Wiedenheft B, Sternberg SH, Doudna JA. RNA-guided genetic silencing systems in bacteria and archaea. Nature. 2012;482:331-8. https://doi.org/10. 1038/nature10886.

143. Gasiunas G, Barrangou R, Horvath P, Siksnys V. Cas9-crRNA ribonucleoprotein complex mediates specific DNA cleavage for adaptive immunity in bacteria. Proc Natl Acad Sci. 2012;109:E2579-86. https://doi.org/ 10.1073/pnas.1208507109.

144. Jinek M, Chylinski K, Fonfara I, Hauer M, Doudna JA, Charpentier E. A programmable dual-RNA-guided DNA endonuclease in adaptive bacterial immunity. Science. 2012;337:816-21. https://doi.org/10.1126/science. 1225829.

145. Jiang W, Bikard D, Cox D, Zhang F, Marraffini LA. RNA-guided editing of bacterial genomes using CRISPR-Cas systems. Nat Biotechnol. 2013;31:233-9. https://doi.org/10.1038/nbt.2508.

146. Sander JD, Joung JK. CRISPR-Cas systems for editing, regulating and targeting genomes. Nat Biotechnol. 2014;32:347-55. https://doi.org/10.1038/nbt.2842.

147. Ran FA, Hsu PD, Lin C, Gootenberg JS, Konermann S, Trevino AE, et al. Double nicking by RNA-guided CRISPR Cas9 for enhanced genome editing specificity. Cell. 2013;154:1380-9. https://doi.org/10.1016/j.cell.2013.08.021.

148. Ran FA, Hsu PD, Wright J, Agarwala V, Scott DA, Zhang F. Genome engineering using the CRISPR-Cas9 system. Nat Protoc. 2013:8:2281-308. https://doi.org/10.1038/nprot.2013.143.

149. Mei $Y$, Wang $Y$, Chen H, Sun ZS, Ju X-D. Recent progress in CRISPR/Cas9 technology. J Genet Genomics. 2016;43:63-75. https://doi.org/10.1016/j.jgg 2016.01.001.

150. Marraffini LA, Sontheimer EJ. CRISPR interference limits horizontal gene transfer in staphylococci by targeting DNA. Science. 2008;322:1843-5. https://doi.org/10.1126/science.1165771.

151. A a G, Klumpe HE, Luo ML, Selle K, Barrangou R, Beisel CL. Programmable removal of bacterial strains by use of genome-targeting CRISPR-Cas systems. MBio. 2014;5:e00928-13. https://doi.org/10.1128/mBio.00928-13.

152. Caliando BJ, Voigt CA. Targeted DNA degradation using a CRISPR device stably carried in the host genome. Nat Commun. 2015;6:6989. https://doi. org/10.1038/ncomms7989.

153. Makarova KS, Haft DH, Barrangou R, Brouns SJJ, Charpentier E, Horvath P, et al. Evolution and classification of the CRISPR-Cas systems. Nat Rev Microbiol. 2011;9:467-77. https://doi.org/10.1038/nrmicro2577.
154. Semenova E, Jore MM, Datsenko KA, Semenova A, Westra ER, Wanner B, et al. Interference by clustered regularly interspaced short palindromic repeat (CRISPR) RNA is governed by a seed sequence. Proc Natl Acad Sci U S A. 2011;108:10098-103. https://doi.org/10.1073/pnas.1104144108.

155. Mojica FJM, Díez-Villaseñor C, García-Martínez J, Almendros C. Short motif sequences determine the targets of the prokaryotic CRISPR defence system. Microbiology. 2009;155(Pt 3):733-40. https://doi.org/10. 1099/mic.0.023960-0.

156. Wiedenheft B. In defense of phage: viral suppressors of CRISPR-mediated adaptive immunity in bacteria. RNA Biol. 2013;10:886-90. https://doi.org/10. 4161/rna.23591.

157. Jiang W, Bikard D, Cox D, Zhang F, Marraffini LA. RNA-guided editing of bacterial genomes using CRISPR-Cas systems. Nat Biotechnol. 2013;31:233-9.

158. Niewoehner O, Jinek M, Doudna JA. Evolution of CRISPR RNA recognition and processing by Cas6 endonucleases. Nucleic Acids Res. 2014:42:1341-53. https://doi.org/10.1093/nar/gkt922.

159. Marraffini LA, Sontheimer EJ. Self versus non-self discrimination during CRISPR RNA-directed immunity. Nature. 2010;463:568-71. https://doi.org/10. 1038/nature08703.

160. HKU Hongkong 2015. http://2015.igem.org/Team:Hong_Kong_HKU. Accessed 23 Jun 2017

161. Bernard P, Couturier M. Cell killing by the F plasmid C CdB protein involves poisoning of DNA-topoisomerase II complexes. J Mol Biol. 1992;226:735-45. https://doi.org/10.1016/0022-2836(92)90629-X.

162. Jia B, Qi H, Li BZ, Pan S, Liu D, Liu H, et al. Orthogonal ribosome biofirewall. ACS Synth Biol. 2017;6:2108-17

163. Schmidt M. Xenobiology: a new form of life as the ultimate biosafety tool. BioEssays. 2010;32:322-31. https://doi.org/10.1002/bies.200900147.

164. Schmidt M, de Lorenzo V. Synthetic constructs in/for the environment: managing the interplay between natural and engineered biology. FEBS Lett. 2012;586:2199-206. https://doi.org/10.1016/j.febslet.2012.02.022.

165. Pinheiro VB, Holliger P. The XNA world: progress towards replication and evolution of synthetic genetic polymers. Curr Opin Chem Biol. 2012;16:245-52. https://doi.org/10.1016/j.cbpa.2012.05.198.

166. Nielsen KM, Johnsen PJ, Bensasson D, Daffonchio D. Release and persistence of extracellular DNA in the environment. Environ Biosaf Res. 2007;6:37-53. https://doi.org/10.1051/ebr:2007031.

167. Plos K, Hull SI, Hull RA, Levin BR, Orskov I, Orskov F, et al. Distribution of the P-associated-pilus (pap) region among Escherichia coli from natural sources: evidence for horizontal gene transfer. Infect Immun. 1989;57:1604-11. http://www.ncbi.nlm.nih.gov/pubmed/2565294

168. de la Cruz F, Davies J. Horizontal gene transfer and the origin of species: lessons from bacteria. Trends Microbiol. 2000;8:128-33. https://doi.org/10. 1016/S0966-842X(00)01703-0.

169. Davison J. Genetic exchange between Bacteria in the environment. Plasmid. 1999;42:73-91. https://doi.org/10.1006/plas.1999.1421.

170. Acevedo-Rocha CG, Budisa N. On the road towards chemically modified organisms endowed with a genetic firewall. Angew Chem Int Ed Engl. 2011:50:6960-2. https://doi.org/10.1002/anie.201103010.

171. Marlière $P$. The farther, the safer: a manifesto for securely navigating synthetic species away from the old living world. Syst Synth Biol. 2009;3:77-84. https://doi.org/10.1007/s11693-009-9040-9.

172. Herdewijn $P$, Marlière $P$. Toward safe genetically modified organisms through the chemical diversification of nucleic acids. Chem Biodivers. 2009;6:791-808. https://doi.org/10.1002/cbdv.200900083.

173. Agostini F, Völler J-S, Koksch B, Acevedo-Rocha CG, Kubyshkin V, Budisa N. Biocatalysis with unnatural amino acids: enzymology meets Xenobiology. Angew Chem Int Ed Engl. 2017;56:9680-703. https://doi.org/10.1002/anie.201610129.

174. Martinot TA, Benner SA. Artificial genetic systems: exploiting the "aromaticity" formalism to improve the tautomeric ratio for Isoguanosine derivatives. J Org Chem. 2004;69:3972-5. https://doi.org/10.1021/jo0497959.

175. Jiang D, Seela F. Oligonucleotide duplexes and multistrand assemblies with 8-Aza-2'-deoxyisoguanosine: a fluorescent isoG d shape mimic expanding the genetic alphabet and forming lonophores. J Am Chem Soc. 2010;132: 4016-24. https://doi.org/10.1021/ja910020n.

176. Kwok R. Chemical biology: DNA's new alphabet. Nature. 2012:491:516-8. https://doi.org/10.1038/491516a.

177. Zhang $Y$, Lamb BM, Feldman AW, Zhou AX, Lavergne $T$, Li L, et al. A semisynthetic organism engineered for the stable expansion of the genetic alphabet. Proc Natl Acad Sci. 2017;114:1317-22. https://doi.org/10.1073/ pnas. 1616443114 
178. Yamashige R, Kimoto M, Takezawa Y, Sato A, Mitsui T, Yokoyama S, et al Highly specific unnatural base pair systems as a third base pair for PCR amplification. Nucleic Acids Res. 2012;40:2793-806.

179. Seela F, Peng X, Li H. Base-pairing, tautomerism, and mismatch discrimination of 7-halogenated 7-deaza-2'-deoxyisoguanosine: oligonucleotide duplexes with parallel and antiparallel chain orientation. J Am Chem Soc. 2005;127: 7739-51. https://doi.org/10.1021/ja0425785.

180. Switzer C, Moroney SE, Benner SA. Enzymatic incorporation of a new base pair into DNA and RNA. J Am Chem Soc. 1989;111:8322-3. https://doi.org/ 10.1021/ja00203a067

181. Yang Z, Chen F, Alvarado JB, Benner SA. Amplification, mutation, and sequencing of a six-letter synthetic genetic system. J Am Chem Soc. 2011; 133:15105-12. https://doi.org/10.1021/ja204910n.

182. Pinheiro VB, Taylor Al, Cozens C, Abramov M, Renders M, Zhang S, et al. Synthetic genetic polymers capable of heredity and evolution. Science. 2012;336:341-4. https://doi.org/10.1126/science.1217622.

183. Dunn DB, Smith JD. Effects of 5-halogenated uracils on the growth of Escherichia coli and their incorporation into deoxyribonucleic acids. Biochem J. 1957;67:494-506. https://doi.org/10.1042/bj0670494.

184. Marlière $P$, Patrouix J, Döring $V$, Herdewijn $P$, Tricot $S$, Cruveiller $S$, et al. Chemical evolution of a bacterium's genome. Angew Chem Int Ed Engl. 2011;50:7109-14

185. Yang Z, Chen F, Chamberlin SG, Benner SA. Expanded genetic alphabets in the polymerase chain reaction. Angew Chem Int Ed Engl. 2010;49:177-80. https://doi.org/10.1002/anie.200905173.

186. Laos R, Thomson JM, Benner SA. DNA polymerases engineered by directed evolution to incorporate non-standard nucleotides. Front Microbiol. 2014;5: 1-14. https://doi.org/10.3389/fmicb.2014.00565.

187. Chen F, Yang Z, Yan M, Alvarado JB, Wang G, Benner SA. Recognition of an expanded genetic alphabet by type-II restriction endonucleases and their application to analyze polymerase fidelity. Nucleic Acids Res. 2011;39:3949-61. https:/doi.org/10.1093/nar/gkq1274.

188. Leal NA, Kim H-J, Hoshika S, Kim M-J, Carrigan MA, Benner SA. Transcription, reverse transcription, and analysis of RNA containing artificial genetic components. ACS Synth Biol. 2015;4:407-13. https://doi.org/10.1021/ sb500268n.

189. Georgiadis MM, Singh I, Kellett WF, Hoshika S, Benner SA, Richards NGJ. Structural basis for a six nucleotide genetic alphabet. J Am Chem Soc. 2015;137:6947-55. https://doi.org/10.1021/jacs.5b03482.

190. Takezawa Y, Shionoya M. Metal-mediated DNA Base pairing: alternatives to hydrogen-bonded Watson-Crick Base pairs. Acc Chem Res. 2012;45:2066-76. https://doi.org/10.1021/ar200313h.

191. Atwell S, Meggers E, Spraggon G, Schultz PG. Structure of a copperMediated Base pair in DNA. J Am Chem Soc. 2001;123:12364-7. https://doi. org/10.1021/ja011822e

192. Weizman H, Tor Y. 2,2'-Bipyridine Ligandoside: a novel building block for modifying DNA with intra-duplex metal complexes. J Am Chem Soc. 2001; 123:3375-6. https://doi.org/10.1021/ja005785n.

193. Seo YJ, Matsuda S, Romesberg FE. Transcription of an expanded genetic alphabet. J Am Chem Soc. 2009;131:5046-7. https://doi.org/10.1021/ja9006996.

194. Malyshev DA, Dhami K, Lavergne T, Chen T, Dai N, Foster JM, et al. A semisynthetic organism with an expanded genetic alphabet. Nature. 2014;509: 385-8. https://doi.org/10.1038/nature13314.

195. Liu H, Gao J, Lynch SR, Saito YD, Maynard L, Kool ET. A Four-Base paired genetic Helix with expanded size. Science. 2003;302:868-71. https://doi.org/ 10.1126/science.1088334

196. Liu H, Gao J, Maynard L, Saito YD, Kool ET. Toward a new genetic system with expanded dimensions: size-expanded analogues of deoxyadenosine and thymidine. J Am Chem Soc. 2004;126:1102-9. https://doi.org/10.1021/ ja038384r.

197. Krueger AT, Peterson LW, Chelliserry J, Kleinbaum DJ, Kool ET. Encoding phenotype in Bacteria with an alternative genetic set. J Am Chem Soc. 2011;133:18447-51. https://doi.org/10.1021/ja208025e.

198. Lee AHF, Kool ET. A new Four-Base genetic Helix, yDNA, composed of widened Benzopyrimidine-purine pairs. J Am Chem Soc. 2005;127:3332-8. https://doi.org/10.1021/ja0430604

199. Lu H, Lynch SR, Lee AHF, Kool ET. Structure and replication of yDNA: a novel genetic set widened by benzo-homologation. Chembiochem. 2009;10:2530-8. https://doi.org/10.1002/cbic.200900434.

200. Hendrix C, Rosemeyer H, De Bouvere B, Van Aerschot A, Seela F, Herdewijn P. 1',5'-Anhydrohexitol oligonucleotides: hybridisation and strand displacement with Oligoribonucleotides, interaction with RNase $\mathrm{H}$ and HIV reverse transcriptase. Chem Eur J. 1997;3:1513-20. https://doi.org/10.1002/ chem.19970030920.

201. Schoning K-U, Scholz P, Guntha S, Wu X, Krishnamurthy R, Eschenmoser A Chemical etiology of nucleic acid structure: the a-Threofuranosyl-(3'-2') oligonucleotide system. Science. 2000;290:1347-51. https://doi.org/10.1126/ science.290.5495.1347

202. Ichida JK, Horhota A, Zou K, McLaughlin LW, Szostak JW. High fidelity TNA synthesis by Therminator polymerase. Nucleic Acids Res. 2005;33:5219-25. https://doi.org/10.1093/nar/gki840.

203. Zhang L, Peritz A, Meggers E. A simple glycol nucleic acid. J Am Chem Soc. 2005;127:4174-5. https://doi.org/10.1021/ja042564z.

204. Nauwelaerts K, Lescrinier E, Sclep G, Herdewijn P. Cyclohexenyl nucleic acids: conformationally flexible oligonucleotides. Nucleic Acids Res. 2005;33: 2452-63. https://doi.org/10.1093/nar/gki538.

205. Yount RG, Babcock D, Ballantyne W, Ojala D. Adenylyl imidiodiphosphate, an adenosine triphosphate analog containing a P-N-P linkage. Biochemistry. 1971;10:2484-9. https://doi.org/10.1021/bi00789a009.

206. Goody RS, Eckstein F. Thiophosphate analogs of nucleoside Di- and triphosphates. J Am Chem Soc. 1971;93:6252-7. https://doi.org/10.1021/ja00752a042.

207. Terrazas M, Marlière $P$, Herdewijn P. Enzymatically catalyzed DNA synthesis using L-asp-dGMP, L-asp-dCMP, and L-asp-dTMP. Chem Biodivers. 2008;5: 31-9. https://doi.org/10.1002/cbdv.200890013.

208. Stahl FW. The amber mutants of phage T4. Genetics. 1995;141:439-42. http://www.ncbi.n/m.nih.gov/pubmed/8647382. Accessed 30 May 2017

209. Lajoie MJ, Rovner AJ, Goodman DB, Aerni H, Haimovich AD, Kuznetsov G, et al. Expand biological functions. Science. 2013;342:357-60.

210. Heider J, Baron C, Böck A. Coding from a distance: dissection of the mRNA determinants required for the incorporation of selenocysteine into protein. EMBO J. 1992;11:3759-66.

211. Blight SK, Larue RC, Mahapatra A, Longstaff DG, Chang E, Zhao G, et al. Direct charging of tRNA CUA with pyrrolysine in vitro and in vivo. Nature. 2004;431:333-5. https://doi.org/10.1038/nature02895.

212. Mukai T, Hayashi A, Iraha F, Sato A, Ohtake K, Yokoyama S, et al. Codon reassignment in the Escherichia coli genetic code. Nucleic Acids Res. 2010; 38:8188-95. https://doi.org/10.1093/nar/gkq707.

213. Ohtake K, Sato A, Mukai T, Hino N, Yokoyama S, Sakamoto K. Efficient decoding of the UAG triplet as a full-fledged sense codon enhances the growth of a prfA-deficient strain of Escherichia coli. J Bacteriol. 2012;194: 2606-13. https://doi.org/10.1128/JB.00195-12.

214. Lajoie MJ, Kosuri S, Mosberg JA, Gregg CJ, Zhang D, Church GM. Probing the limits of genetic recoding in essential genes. Science. 2013;342:361-3. https://doi.org/10.1126/science.1241460.

215. Miller C, Bröcker MJ, Prat L, Ip K, Chirathivat N, Feiock A, et al. A synthetic tRNA for EF-Tu mediated selenocysteine incorporation in vivo and in vitro FEBS Lett. 2015;589:2194-9. https://doi.org/10.1016/j.febslet.2015.06.039.

216. Crnković A, Suzuki T, Söll D, Reynolds NM. Pyrrolysyl-tRNA Synthetase, an aminoacyl-tRNA Synthetase for genetic code expansion. Croat Chem Acta. 2016;89:134-9. https://doi.org/10.5562/cca2825.

217. Miller JH, Coulondre C, Hofer M, Schmeissner U, Sommer H, Schmitz A, et al. Genetic studies of the lac repressor. IX. Generation of altered proteins by the suppression of nonsence mutations. J Mol Biol. 1979;131:191-222. https://doi.org/10.1016/0022-2836(79)90073-1.

218. Isaacs FJ, Carr PA, Wang HH, Lajoie MJ, Sterling B, Kraal L, et al. Precise manipulation of chromosomes in vivo enables genome-wide codon replacement. Science. 2011;333:348-53. https://doi.org/10.1126/science.1205822.

219. Lajoie MJ, Rovner AJ, Goodman DB, Aerni H-R, Haimovich AD, Kuznetsov G, et al. Genomically recoded organisms expand biological functions. Science. 2013;342:357-60. https://doi.org/10.1126/science.1241459.

220. Liu CC, Schultz PG. Adding new chemistries to the genetic code. Annu Rev Biochem. 2010;79:413-44. https://doi.org/10.1146/annurev.biochem.052308. 105824.

221. Kato $Y$. An engineered bacterium auxotrophic for an unnatural amino acid: a novel biological containment system. PeerJ. 2015;3:e1247. https://doi.org/ 10.7717/peerj.1247.

222. Mukai T, Yamaguchi A, Ohtake K, Takahashi M, Hayashi A, Iraha F, et al. Reassignment of a rare sense codon to a non-canonical amino acid in Escherichia coli. Nucleic Acids Res. 2015:43:8111-22. https://doi.org/10.1093/ nar/gkv787

223. De Simone A, Acevedo-Rocha CG, Hoesl MG, Budisa N. Towards reassignment of the methionine codon $A \cup G$ to two different noncanonical 
amino acids in bacterial translation. Croat Chem Acta. 2016;89 https://doi. org/10.5562/cca2915.

224. Cui Z, Mureev S, Polinkovsky ME, Tnimov Z, Guo Z, Durek T, et al. Combining sense and nonsense codon reassignment for site-selective protein modification with unnatural amino acids. ACS Synth Biol. 2017;6: 535-44. https://doi.org/10.1021/acssynbio.6b00245.

225. Hoesl MG, Oehm S, Durkin P, Darmon E, Peil L, Aerni H-R, et al. Chemical evolution of a bacterial proteome. Angew Chem Int Ed Engl. 2015;54: 10030-4. https://doi.org/10.1002/anie.201502868.

226. Wang L, Xie J, Schultz PG. Expanding the genetic code. Annu Rev Biophys Biomol Struct. 2006;35:225-49. https://doi.org/10.1146/annurev.biophys.35. 101105.121507.

227. Minaba M, Kato Y. High-yield, zero-leakage expression system with a translational switch using site-specific unnatural amino acid incorporation. Appl Environ Microbiol. 2014;80:1718-25. https://doi.org/10.1128/AEM. 03417-13.

228. Magliery TJ, Anderson JC, Schultz PG. Expanding the genetic code: selection of efficient suppressors of four-base codons and identification of "shifty" four-base codons with a library approach in Escherichia coli. J Mol Biol. 2001; 307:755-69. https://doi.org/10.1006/jmbi.2001.4518.

229. Neumann H, Wang K, Davis L, Garcia-Alai M, Chin JW. Encoding multiple unnatural amino acids via evolution of a quadruplet-decoding ribosome. Nature. 2010;464:441-4. https://doi.org/10.1038/nature08817.

230. Kramer EB, Farabaugh PJ. The frequency of translational misreading errors in E. coli is largely determined by tRNA competition. RNA. 2006;13:87-96. https://doi.org/10.1261/rna.294907.

231. Rackham O, Chin JW. A network of orthogonal ribosome-mRNA pairs. Nat Chem Biol. 2005;1:159-66. https://doi.org/10.1038/nchembio719.

232. Wang K, Neumann H, Peak-Chew SY, Chin JW. Evolved orthogonal ribosomes enhance the efficiency of synthetic genetic code expansion. Nat Biotechnol. 2007;25:770-7. https://doi.org/10.1038/nbt1314.

233. TU Darmstadt 2016. http://2016.igem.org/Team:TU_Darmstadt. Accessed 4 Jun 2017.

234. Zhang Y, Wang L, Schultz PG, Wilson IA. Crystal structures of apo wild-type M. jannaschii tyrosyl-tRNA synthetase (TyrRS) and an engineered TyrRS specific for O-methyl-L-tyrosine. Protein Sci. 2005;14:1340-9. https://doi.org/ 10.1110/ps.041239305.

235. Austin Texas 2014. http://2014.igem.org/Team:Austin_Texas. Accessed 4 Jun 2017.

236. Schaller K, Nomura M. Colicin E2 is a DNA endonuclease. Proc Natl Acad Sci. 1976;73:3989-93. https://doi.org/10.1073/pnas.73.11.3989.

237. Wolfe SA, Grant RA, Pabo CO. Structure of a designed dimeric zinc finger protein bound to DNA. Biochemistry. 2003;42:13401-9. https://doi.org/10. 1021/bi034830b.

238. Rekas A, Alattia J-R, Nagai T, Miyawaki A, Ikura M. Crystal structure of Venus, a yellow fluorescent protein with improved maturation and reduced environmental sensitivity. J Biol Chem. 2002;277:50573-8. https://doi.org/10. 1074/jbc.M209524200.

239. Bielefeld-CeBiTec. Expanding the genetic code; 2017. https://doi.org/10. 13140/RG.2.2.20342.91203.

240. Acevedo-Rocha CG, Fang G, Schmidt M, Ussery DW, Danchin A. From essential to persistent genes: a functional approach to constructing synthetic life. Trends Genet. 2013;29:273-9. https://doi.org/10.1016/j.tig.2012. 11.001 .

241. Maniloff J. The minimal cell genome: "on being the right size". Proc Natl Acad Sci. 1996;93:10004-6. https://doi.org/10.1073/pnas.93.19.10004.

242. Itaya M. An estimation of minimal genome size required for life. FEBS Lett. 1995;362:257-60. https://doi.org/10.1016/0014-5793(95)00233-Y.

243. Arigoni F, Talabot F, Peitsch M, Edgerton MD, Meldrum E, Allet E, et al. A genome-based approach for the identification of essential bacterial genes. Nat Biotechnol. 1998;16:851-6. https://doi.org/10.1038/nbt0998-851.

244. Mushegian A. The minimal genome concept. Curr Opin Genet Dev. 1999;9: 709-14. https://doi.org/10.1016/50959-437X(99)00023-4.

245. Hutchison CA, Chuang R-Y, Noskov VN, Assad-Garcia N, Deerinck TJ, Ellisman $\mathrm{MH}$, et al. Design and synthesis of a minimal bacterial genome. Science. 2016;351:aad6253. https://doi.org/10.1126/science.aad6253.

246. Gil R, Silva FJ, Peretó J, Pereto J. Determination of the Core of a minimal bacterial gene set. Microbiol Mol Biol Rev. 2004;68:518-37.

247. Smalley DJ, Whiteley M, Conway T. In search of the minimal Escherichia coli genome. Trends Microbiol. 2003;11:6-8. https://doi.org/10.1016/50966842X(02)00008-2.
248. Forsyth RA, Haselbeck RJ, Ohlsen KL, Yamamoto RT, Xu H, Trawick JD, et al. A genome-wide strategy for the identification of essential genes in Staphylococcus aureus. Mol Microbiol. 2002;43:1387-400. https://doi.org/10. 1046/j.1365-2958.2002.02832.x.

249. Ji Y, Zhang B, Van Horn SF, Warren P, Woodnutt G, Burnham MKR, et al. Identification of critical staphylococcal genes using conditional phenotypes generated by antisense RNA. Science. 2001;293:2266-9. https://doi.org/10. 1126/science.1063566.

250. Juhas M, Eberl L, Glass Jl. Essence of life: essential genes of minimal genomes. Trends Cell Biol. 2011;21:562-8. https://doi.org/10.1016/j.tcb.2011. 07.005.

251. Lluch-Senar M, Delgado J, Chen W-H, Llorens-Rico V, O'Reilly FJ, Wodke JA, et al. Defining a minimal cell: essentiality of small ORFs and ncRNAs in a genome-reduced bacterium. Mol Syst Biol. 2015;11:780. https://doi.org/10. 15252/msb.20145558.

252. Jewett MC, Forster AC. Update on designing and building minimal cells. Curr Opin Biotechnol. 2010;21:697-703. https://doi.org/10.1016/j.copbio. 2010.06.008

253. Akerley BJ, Rubin EJ, Novick VL, Amaya K, Judson N, Mekalanos JJ. A genome-scale analysis for identification of genes required for growth or survival of Haemophilus influenzae. Proc Natl Acad Sci. 2002;99:966-71. https://doi.org/10.1073/pnas.012602299.

254. Molzen TE, Burghout P, Bootsma HJ, Brandt CT, van der Gaast-de Jongh CE, Eleveld MJ, et al. Genome-wide identification of Streptococcus pneumoniae genes essential for bacterial replication during experimental meningitis. Infect Immun. 2011;79:288-97. https://doi.org/10.1128/IAl.00631-10.

255. Glass Jl, Assad-Garcia N, Alperovich N, Yooseph S, Lewis MR, Maruf M, et al. Essential genes of a minimal bacterium. Proc Natl Acad Sci. 2006;103:42530. https://doi.org/10.1073/pnas.0510013103.

256. Hutchison CA III, Peterson SN, Gill SR, Cline RT, White O, Fraser CM, et al. Global transposon mutagenesis and a minimal mycoplasma genome. Science. 1999;286:2165-9. https://doi.org/10.1126/science.286.5447.2165.

257. Gil R, Sabater-Munoz B, Latorre A, Silva FJ, Moya A. Extreme genome reduction in Buchnera spp.: toward the minimal genome needed for symbiotic life. Proc Natl Acad Sci. 2002;99:4454-8. https://doi.org/10.1073/ pnas.062067299.

258. Giaever G, Chu AM, Ni L, Connelly C, Riles L, Véronneau S, et al. Functional profiling of the Saccharomyces cerevisiae genome. Nature. 2002;418:387-91. https://doi.org/10.1038/nature00935.

259. Unthan S, Baumgart M, Radek A, Herbst M, Siebert D, Brühl N, et al. Chassis organism from Corynebacterium glutamicum - a top-down approach to identify and delete irrelevant gene clusters. Biotechnol J. 2015;10:290-301.

260. Yu BJ, Sung BH, Koob MD, Lee CH, Lee JH, Lee WS, et al. Minimization of the Escherichia coli genome using a Tn5-targeted Cre/loxP excision system. Nat Biotechnol. 2002;20:1018-23. https://doi.org/10.1038/nbt740.

261. Baba T, Ara T, Hasegawa M, Takai Y, Okumura Y, Baba M, et al. Construction of Escherichia coli K-12 in-frame, single-gene knockout mutants: the Keio collection. Mol Syst Biol. 2006;2:2006.0008. https://doi.org/10.1038/ msb4100050.

262. Gerdes SY, Scholle MD, Campbell JW, Balazsi G, Ravasz E, Daugherty MD, et al. Experimental determination and system level analysis of essential genes in Escherichia coli MG1655. J Bacteriol. 2003;185:5673-84. https://doi. org/10.1128/JB.185.19.5673-5684.2003.

263. Fraser CM, Gocayne JD, White O, Adams MD, Clayton RA, Fleischmann RD, et al. The minimal gene complement of Mycoplasma genitalium. Science. 1995;270:397-404. https://doi.org/10.1126/science.270.5235.397.

264. Mushegian AR, Koonin EV. A minimal gene set for cellular life derived by comparison of complete bacterial genomes. Proc Natl Acad Sci. 1996;93: 10268-73. https://doi.org/10.1073/pnas.93.19.10268.

265. Gibson DG, Glass Jl, Lartigue C, Noskov VN, Chuang R-Y, Algire MA, et al. Creation of a bacterial cell controlled by a chemically synthesized genome. Science. 2010;329:52-6. https://doi.org/10.1126/science.1190719.

266. Alberta 2009. http://2009.igem.org/Team:Alberta. Accessed 4 Jun 2017.

267. ETH Zurich 2008. http://2008.igem.org/Team:ETH_Zurich. Accessed 4 Jun 2017.

268. UESTC 2015. http://2015.igem.org/Team:UESTC_Software. Accessed 4 Jun 2017

269. Gale EF, Folkes JP. Effect of nucleic acids on protein synthesis and amino-acid incorporation in disrupted staphylococcal cells. Nature. 1954;173:1223-7. https://doi.org/10.1038/1731223a0. 
270. Nirenberg MW, Matthaei JH. The dependence of cell-free protein synthesis in E. coli upon naturally occurring or synthetic polyribonucleotides. Proc Natl Acad Sci. 1961;47:1588-602. https://doi.org/10.1073/pnas.47.10.1588.

271. Hodgman CE, Jewett MC. Cell-free synthetic biology: thinking outside the cell. Metab Eng. 2012;14:261-9. https://doi.org/10.1016/j.ymben.2011.09.002.

272. Yang J, Kanter G, Voloshin A, Michel-Reydellet N, Velkeen $H$, Levy $R$, et al. Rapid expression of vaccine proteins for B-cell lymphoma in a cell-free system. Biotechnol Bioeng. 2005;89:503-11.

273. Smith MT, Wu JC, Varner CT, Bundy BC. Enhanced protein stability through minimally invasive, direct, covalent, and site-specific immobilization. Biotechnol Prog. 2013;29:247-54.

274. Kitaoka Y, Nishimura N, Niwano M. Cooperativity of stabilized mRNA and enhanced translation activity in the cell-free system. J Biotechnol. 1996;48:1-8.

275. Matveev SV, Vinokurov LM, Shaloiko LA, Davies C, Matveeva EA, Alakhov YB. Effect of the ATP level on the overall protein biosynthesis rate in a wheat germ cell-free system. Biochim Biophys Acta. 1996;1293:207-12.

276. Shimizu Y, Inoue A, Tomari Y, Suzuki T, Yokogawa T, Nishikawa K, et al. Cellfree translation reconstituted with purified components. Nat Biotechnol. 2001;19:751-5. https://doi.org/10.1038/90802.

277. Shrestha P, Holland TM, Bundy BC. Streamlined extract preparation for Escherichia coli-based cell-free protein synthesis by sonication or bead vortex mixing. BioTechniques. 2012;53:163-74.

278. Smith MT, Bennett AM, Hunt JM, Bundy BC. Creating a completely "cell-free" system for protein synthesis. Biotechnol Prog. 2015;31:1716-9. https://doi. org/10.1002/btpr.2157.

279. Kim D-M, Kigawa T, Choi C-Y, Yokoyama S. A highly efficient cell-free protein synthesis system from Escherichia coli. Eur J Biochem. 1996;239:881-6. https:// doi.org/10.1111/j.1432-1033.1996.0881u.x.

280. Bielefeld-CeBiTec 2015. http://2015.igem.org/Team:Bielefeld-CeBiTec. Accessed 21 Apr 2017

281. Kwon Y-C, Jewett MC. High-throughput preparation methods of crude extract for robust cell-free protein synthesis. Sci Rep. 2015;5:8663. https:// doi.org/10.1038/srep08663.

282. Edinburgh 2015. http://2015.igem.org/Team:Edinburgh. Accessed 21 Apr 2017.

283. Exeter 2015. http://2015.igem.org/Team:Exeter. Accessed 21 Apr 2017.

284. Freiburg 2015. http://2015.igem.org/Team:Freiburg. Accessed 21 Apr 2017.

285. iGEM Lethbridge 2017. http://2017.igem.org/Team:Lethbridge. Accessed 26 Mar 2017

286. Kailasapathy K. Microencapsulation of probiotic bacteria: technology and potential applications. Curr Issues Intest Microbiol. 2002;3:39-48. http:// www.ncbi.nlm.nih.gov/pubmed/12400637.

287. Tatiya PD, Hedaoo RK, Mahulikar PP, Gite W. Novel polyurea microcapsules using dendritic functional monomer: synthesis, characterization, and its use in self-healing and anticorrosive polyurethane coatings. Ind Eng Chem Res. 2013;52:1562-70.

288. Puddu M, Paunescu D, Stark WJ, Grass RN. Magnetically recoverable, thermostable, hydrophobic DNA/silica encapsulates and their application as invisible oil tags. ACS Nano. 2014;8:2677-85.

289. Hedaoo RK, Gite W. Renewable resource-based polymeric microencapsulation of natural pesticide and its release study: an alternative green approach. RSC Adv. 2014;4:18637. https://doi.org/10. 1039/c4ra01558d.

290. Orive G, De Castro M, Ponce S, Hernández RM, Gascón AR, Bosch M, et al. Long-term expression of erythropoietin from myoblasts immobilized in biocompatible and neovascularized microcapsules. Mol Ther. 2005;12:283-9.

291. Murua A, de Castro M, Orive G, Hernández RM, Pedraz JL. In vitro characterization and in vivo functionality of erythropoietin-secreting cells immobilized in alginatepoly-L-lysine-alginate microcapsules. Biomacromolecules. 2007;8:3302-7.

292. Rathore S, Desai PM, Liew CV, Chan LW, Heng PWS. Microencapsulation of microbial cells. J Food Eng. 2013;116:369-81. https://doi.org/10.1016/j. jfoodeng.2012.12.022.

293. Smidsrød O, Skjåk-Braek G. Alginate as immobilization matrix for cells. Trends Biotechnol. 1990;8:71-8. https://doi.org/10.1016/0167-7799(90)90139-O.

294. John RP, Tyagi RD, Brar SK, Surampalli RY, Prévost D. Bio-encapsulation of microbial cells for targeted agricultural delivery. Crit Rev Biotechnol. 2011;31:211-26

295. Avnir D, Braun S, Lev O, Ottolenghi M. Enzymes and other proteins entrapped in sol-gel materials. Chem Mater. 1994;6:1605-14.

296. Zink JI, Yamanaka SA, Ellerby LM, Valentine JS, Nishida F, Dunn B. Biomolecular materials based on sol-gel encapsulated proteins - code: G1. J Sol-Gel Sci Technol. 1994;2:791-5.
297. Pankratov I, Lev O. Sol-gel derived renewable-surface biosensors. J Electroanal Chem. 1995;393:35-41.

298. Nassif N, Bouvet O, Noelle Rager M, Roux C, Coradin T, Livage J. Living bacteria in silica gels. Nat Mater. 2002;1:42-4.

299. Dusseault J, Langlois G, Meunier MC, Ménard M, Perreault C, Hallé JP. The effect of covalent cross-links between the membrane components of microcapsules on the dissemination of encapsulated malignant cells. Biomaterials. 2008;29:917-24.

300. Zimmermann H, Wählisch F, Baier C, Westhoff M, Reuss R, Zimmermann D, et al. Physical and biological properties of barium cross-linked alginate membranes. Biomaterials. 2007:28:1327-45.

301. Shen F, Mazumder MAJ, Burke NAD, Stöver HDH, Potter MA. Mechanically enhanced microcapsules for cellular gene therapy. J Biomed Mater Res B Appl Biomater. 2009;90(B):350-61.

302. Paris Saclay 2015. http://2015.igem.org/Team:Paris_Saclay. Accessed 23 Jun 2017.

303. Perullini M, Jobbágy M, Soler-Illia GJAA, Bilmes SA. Cell growth at cavities created inside silica monoliths synthesized by sol-gel. Chem Mater. 2005;17: 3806-8.

304. Perullini M, Orias F, Durrieu C, Jobbágy M, Bilmes SA. Co-encapsulation of Daphnia magna and microalgae in silica matrices, a stepping stone toward a portable microcosm. Biotechnol Rep (Amst). 2014;4:147-50. https://doi. org/10.1016/j.btre.2014.10.002.

305. Birnbaum S, Pendleton R, Larsson PO, Mosbach K. Covalent stabilization of alginate gel for the entrapment of living whole cells. Biotechnol Lett. 1981; 3:393-400.

306. Yamamori T, Yura T. Genetic control of heat-shock protein synthesis and its bearing on growth and thermal resistance in Escherichia coli K-12. Proc Natl Acad Sci U S A. 1982;79:860-4.

307. Fayet O, Ziegelhoffer T, Georgopoulos C. The groES and groEL heat shock gene products of Escherichia coli are essential for bacterial growth at all temperatures. J Bacteriol. 1989;171:1379-85. http://www.pubmedcentral.nih. gov/articlerender.fcgi?artid=209756\&tool=pmcentrez\&rendertype=abstract

308. Zhao K, Liu M, Burgess RR. The global transcriptional response of Escherichia colito induced $\sigma 32$ protein involves $\sigma 32$ regulon activation followed by inactivation and degradation of $\sigma 32$ in vivo. J Biol Chem. 2005;280:1775868. https://doi.org/10.1074/jbc.M500393200.

309. Nonaka G. Regulon and promoter analysis of the $E$. coli heat-shock factor, 632, reveals a multifaceted cellular response to heat stress. Genes Dev. 2006; 20:1776-89. https://doi.org/10.1101/gad.1428206.

310. Wade JT, Roa DC, Grainger DC, Hurd D, Busby SJW, Struhl K, et al. Extensive functional overlap between sigma factors in Escherichia coli. Nat Struct Mol Biol. 2006:13:806-14.

311. Ermolenko DN, Makhatadze Gl. Bacterial cold-shock proteins. Cell Mol Life Sci. 2002;59:1902-13.

312. Horn G, Hofweber R, Kremer W, Kalbitzer HR. Structure and function of bacterial cold shock proteins. Cell Mol Life Sci. 2007:64:1457-70.

313. Mizuno T, Imae Y. Conditional inversion of the thermoresponse in Escherichia coli. J Bacteriol. 1984;159:360-7.

314. Maeda K, Imae Y. Thermosensory transduction in Escherichia coli: inhibition of the thermoresponse by L-serine. Proc Natl Acad Sci U S A. 1979;76:91-5. http://www.pubmedcentral.nih.gov/articlerender.fcgi?artid=382882\&tool= pmcentrez\&rendertype $=$ abstract

315. Salman H, Libchaber A. A concentration-dependent switch in the bacterial response to temperature. Nat Cell Biol. 2007:9:1098-100. https://doi.org/10. 1038/ncb1632.

316. Nara $T$, Lee $L$, Imae $Y$. Thermosensing ability of Trg and tap chemoreceptors in Escherichia coli. J Bacteriol. 1991;173:1120-4.

317. Pruss GJ, Drlicat K. DNA supercoiling and Prokatyotic transcription Minireview. Cell. 1988;56:521-3.

318. Dorman CJ, Corcoran CP. Bacterial DNA topology and infectious disease. Nucleic Acids Res. 2009;37:672-8.

319. Dorman CJ. Flexible response: DNA supercoiling, transcription and bacterial adaptation to environmental stress. Trends Microbiol. 1996:4:214-6.

320. López-García P, Forterre P. DNA topology and the thermal stress response, a tale from mesophiles and hyperthermophiles. BioEssays. 2000;22:738-46.

321. Schlax PJ, Worhunsky DJ. Translational repression mechanisms in prokaryotes. Mol Microbiol. 2003:48:1157-69.

322. Morita MT, Tanaka Y, Kodama TS, Kyogoku Y, Yanagi H, Yura T. Translational induction of heat shock transcription factor 032 : evidence for a built-in RNA thermosensor. Genes Dev. 1999;13:655-65. https:/doi.org/10.1101/gad.13.6.655. 
323. Nocker A, Hausherr T, Balsiger S, Krstulovic NP, Hennecke $H$, Narberhaus F. A mRNA-based thermosensor controls expression of rhizobial heat shock genes. Nucleic Acids Res. 2001;29:4800-7. https://doi.org/10.1093/nar/29. 23.4800 .

324. Johansson J, Mandin P, Renzoni A, Chiaruttini C, Springer M, Cossart P. An RNA thermosensor controls expression of virulence genes in Listeria monocytogenes. Cell. 2002;110:551-61. https://doi.org/10.1016/S00928674(02)00905-4

325. Altuvia S, Kornitzer D, Teff D, Oppenheim AB. Alternative mRNA structures of the $\mathrm{cll}$ gene of bacteriophage $\lambda$ determine the rate of its translation initiation. J Mol Biol. 1989;210:265-80. https://doi.org/10.1016/00222836(89)90329-X.

326. Giuliodori AM, Di Pietro F, Marzi S, Masquida B, Wagner R, Romby P, et al. The cspA mRNA is a Thermosensor that modulates translation of the coldshock protein CspA. Mol Cell. 2010;37:21-33. https://doi.org/10.1016/j. molcel.2009.11.033.

327. Narberhaus F, Waldminghaus T, Chowdhury S. RNA thermometers. FEMS Microbiol Rev. 2006;30:3-16.

328. Sledjeski DD, Gupta A, Gottesman S. The small RNA, DsrA, is essential for the low temperature expression of RpoS during exponential growth in Escherichia coli. EMBO J. 1996:15:3993-4000.

329. Repoila F, Gottesman S. Signal transduction cascade for regulation of RpoS: temperature regulation of DsrA. J Bacteriol. 2001;183:4012-23. https://doi. org/10.1128/JB.183.13.4012-4023.2001.

330. Repoila F, Majdalani N, Gottesman S. Small non-coding RNAs, co-ordinators of adaptation processes in Escherichia coli: the RpoS paradigm. Mol Microbiol. 2003;48:855-61.

331. Ketzer P, Kaufmann JK, Engelhardt S, Bossow S, von Kalle C, Hartig JS, et al. Artificial riboswitches for gene expression and replication control of DNA and RNA viruses. Proc Natl Acad Sci U S A. 2014;111:E554-62. https://doi. org/10.1073/pnas.1318563111.

332. Verhounig A, Karcher D, Bock R. Inducible gene expression from the plastid genome by a synthetic riboswitch. Proc Natl Acad Sci. 2010;107:6204-9. https://doi.org/10.1073/pnas.0914423107.

333. Hurme $R$, Rhen M. Temperature sensing in bacterial gene regulation-what it all boils down to. Mol Microbiol. 1998;30:1-6. http://www.ncbi.nlm.nih.gov/ pubmed/9786180

334. Nagai $H$, Yuzawa $H$, Yura $T$. Interplay of two cis-acting mRNA regions in translational control of $\sigma 32$ synthesis during the heat shock response of Escherichia coli. Proc Natl Acad Sci U S A. 1991;88:10515-9. https://doi.org/ 10.1073/pnas.88.23.10515.

335. Craig EA, Gross CA. Is hsp70 the cellular thermometer? Trends Biochem Sci. 1991;16 C:135-40.

336. Chowdhury S, Maris C, Allain FH-T, Narberhaus F. Molecular basis for temperature sensing by an RNA thermometer. EMBO J. 2006;25:2487-97.

337. Narberhaus F, Weiglhofer W, Fischer HM, Hennecke H. The Bradyrhizobium japonicum rpoH1 gene encoding a sigma 32-like protein is part of a unique heat shock gene cluster together with groESL1 and three small heat shock genes. J Bacteriol. 1996;178:5337-46. http://www.ncbi.nlm.nih.gov/pubmed/ 8808920.

338. Glaser M, Nulty W, Vagelos PR. Role of adenylate kinase in the regulation of macromolecular biosynthesis in a putative mutant of Escherichia coli defective in membrane phospholipid biosynthesis. J Bacteriol. 1975;123:12836.

339. Böck A. Mutation affecting the charging reaction of alanyl-tRNA synthetase from Escherichia coli K 10. Arch Mikrobiol. 1969;68:165-78.

340. McHenry CS, Crow W. DNA polymerase III of Escherichia coli. Purification and identification of subunits. J Biol Chem. 1979;254:1748-53. http://www.jbc. org/content/254/5/1748.abstract

341. Heinrikson RL, Hartley BS. Purification and properties of methionyl-transferribonucleic acid synthetase from Escherichia coli. Biochem J. 1967;105:17-24. https://www.ncbi.nlm.nih.gov/pubmed/3283735.

342. Nellemann LJ, Holm F, Atlung T, Hansen FG. Cloning and characterization of the Escherichia coliphosphoglycerate kinase (pgk) gene. Gene. 1989;77:18591. https://doi.org/10.1016/0378-1119(89)90373-9.

343. Calendar R, Berg P. Purification and physical characterization of Tyrosyl ribonucleic acid Synthetases from Escherichia coli and Bacillus subtilis. Biochemistry. 1966;5:1681-90. https://doi.org/10.1021/bi00869a033.

344. Aramaki H, Yagi N, Suzuki M. Residues important for the function of a multihelical DNA binding domain in the new transcription factor family of cam and tet repressors. Protein Eng. 1995:8:1259-66.
345. Waldminghaus T, Heidrich N, Brantl S, Narberhaus F. FourU: a novel type of RNA thermometer in Salmonella. Mol Microbiol. 2007:65:413-24.

346. TU Delft 2008. http://2008.igem.org/Team:TUDelft/Team. Accessed 23 Jun 2017.

347. NCTU Taiwan 2011. http://2011.igem.org/Team:NCTU_Formosa. Accessed 23 Jun 2017

348. Cormier MJ, Hori K, Anderson JM. Bioluminescence in coelenterates. Biochim Biophys Acta. 1974;346:137-64. https://doi.org/10.1016/03044173(74)90007-X.

349. Cormack BP, Valdivia RH, Falkow S. FACS-optimized mutants of the green fluorescent protein (GFP). Gene. 1996;173:33-8. https://doi.org/10.1016/ 0378-1119(95)00685-0.

350. Schwarz C, Bohne AV, Wang F, Cejudo FJ, Nickelsen J. An intermolecular disulfide-based light switch for chloroplast $p s b D$ gene expression in Chlamydomonas reinhardtii. Plant J. 2012;72:378-89.

351. Taylor BL, Zhulin IB. PAS domains: internal sensors of oxygen, redox potential, and light. Microbiol Mol Biol Rev. 1999:63:479-506.

352. Möglich A, Ayers RA, Moffat K. Design and signaling mechanism of lightregulated histidine kinases. J Mol Biol. 2009;385:1433-44. https://doi.org/10. 1016/j.jmb.2008.12.017

353. Crosson S, Rajagopal S, Moffat K. The LOV domain family: Photoresponsive signaling modules coupled to diverse output domains. Biochemistry. 2003; 42:2-10.

354. Gilles-Gonzalez MA, Ditta GS, Helinski DR. A haemoprotein with kinase activity encoded by the oxygen sensor of Rhizobium meliloti. Nature. 1991; 350:170-2. https://doi.org/10.1038/350170a0.

355. Fischer HM. Genetic regulation of nitrogen fixation in rhizobia. Microbiol Rev. 1994;58:352-86. http://www.pubmedcentral.nih.gov/articlerender. fcgi?artid=372973\&tool=pmcentrez\&rendertype $=$ abstract

356. Losi A, Polverini E, Quest B, Gärtner W. First evidence for phototropinrelated blue-light receptors in prokaryotes. Biophys J. 2002;82:2627-34.

357. Gilles-Gonzalez MA, Gonzalez G, Perutz MF, Kiger L, Marden MC, Poyart C. Heme-based sensors, exemplified by the kinase FixL, are a new class of heme protein with distinctive ligand binding and autoxidation. Biochemistry. 1994;33:8067-73. https://doi.org/10.1021/bi00192a011.

358. Ohlendorf R, Vidavski RR, Eldar A, Moffat $K$, Möglich A. From dusk till dawn: one-plasmid systems for light-regulated gene expression. J Mol Biol. 2012; 416:534-42. https://doi.org/10.1016/j.jmb.2012.01.001.

359. Diensthuber RP, Ohlendorf R, Gleichmann T, Schubert R, Möglich A. Lichtregulierte Genexpression. BIOspektrum. 2013;19:149-51.

360. Yeh K. A cyanobacterial Phytochrome two-component light sensory system. Science. 1997;277:1505-8. https://doi.org/10.1126/science.277.5331.1505.

361. Levskaya A, Chevalier AA, Tabor JJ, Simpson ZB, Lavery LA, Levy M, et al. Synthetic biology: engineering Escherichia coli to see light. Nature. 2005;438: 441-2. https://doi.org/10.1038/nature04405.

362. Utsumi R, Brissette RE, Rampersaud A, Forst SA, Oosawa K, Inouye M. Activation of bacterial porin gene expression by a chimeric signal transducer in response to aspartate. Science. 1989;245:1246-9.

363. Kaneko T, Sato S, Kotani H, Tanaka A, Asamizu E, Nakamura Y, et al. Sequence analysis of the genome of the unicellular cyanobacterium Synechocystis sp. strain PCC6803. II. Sequence determination of the entire genome and assignment of potential protein-coding regions. DNA Res. 1996:3:109-36.

364. Hughes J, Lamparter T, Mittmann F, Hartmann E, Gärtner W, Wilde A, et al. A prokaryotic phytochrome. Nature. 1997;386:663. https://doi.org/10.1038/ 386663a0.

365. Beale SI, Cornejo J. Biosynthesis of Phycobilins. J Biol Chem. 1991;266: 22328-32.

366. Gambetta GA, Lagarias JC. Genetic engineering of phytochrome biosynthesis in bacteria. Proc Natl Acad Sci U S A. 2001;98:10566-71. https:// doi.org/10.1073/pnas.191375198.

367. Uppsala 2011. http://2011.igem.org/Team:Uppsala-Sweden. Accessed 23 Jun 2017

368. Cornell 2011. http://2011.igem.org/Team:Cornell. Accessed 23 Jun 2017.

369. Kunkel TA. DNA replication Fidelity. J Biol Chem. 2004;279:16895-8. https:// doi.org/10.1074/jbc.R400006200.

370. Martinez JL, Baquero F. Mutation frequencies and antibiotic resistance. Antimicrob Agents Chemother. 2000;44:1771-7. https://doi.org/10.1128/ AAC.44.7.1771-1777.2000.

371. Microbiology by numbers. Nat Rev Microbiol. 2011;9:628-8. https://doi.org/ 10.1038/nrmicro2644. 
372. Chakrabarty AM. Genetically-manipulated microorganisms and their products in the oil service industries. Trends Biotechnol. 1985;3:32-9.

373. Rojo F, Pieper D, Engesser K, Knackmuss H, Timmis K. Assemblage of ortho cleavage route for simultaneous degradation of chloro- and methylaromatics. Science. 1987;238:1395-8. https://doi.org/10.1126/science. 3479842.

374. Harvard 2010. http://2010.igem.org/Team:Harvard. Accessed 23 Jun 2017.

375. Virginia 2016. http://2016.igem.org/Team:Virginia. Accessed 23 Jun 2017.

376. METU Ankara 2011. http://2011.igem.org/Team:METU-Ankara. Accessed 23 Jun 2017.

377. NYMU Taipei 2014. http://2014.igem.org/Team:NYMU-Taipei. Accessed 23 Jun 2017.

378. Minnesota 2014. http://2014.igem.org/Team:Minnesota. Accessed 23 Jun 2017.

379. HNU China 2014. http://2014.igem.org/Team:HNU_China. Accessed 23 Jun 2017.

380. Braunschweig 2014. http://2014.igem.org/Team:Braunschweig. Accessed 23 Jun 2017.

381. Tack DS, Ellefson JW, Thyer R, Wang B, Gollihar J, Forster MT, et al. Addicting diverse bacteria to a noncanonical amino acid. Nat Chem Biol. 2016;12:138-40. https:/doi.org/10.1038/nchembio.2002

Ready to submit your research? Choose BMC and benefit from:

- fast, convenient online submission

- thorough peer review by experienced researchers in your field

- rapid publication on acceptance

- support for research data, including large and complex data types

- gold Open Access which fosters wider collaboration and increased citations

- maximum visibility for your research: over $100 \mathrm{M}$ website views per year

At BMC, research is always in progress.

Learn more biomedcentral.com/submissions 